\title{
Recent Trends in Biodiesel and Biogas Production
}

\section{Arijana Bušić' , Semjon \\ Kundas², Galina Morzak3, \\ Halina Belskaya ${ }^{3}$, Nenad \\ Marđetko', Mirela Ivančić \\ Šantek', Draženka \\ Komes' ${ }^{1}$, Srđan Novak' \\ and Božidar Šantek*}

'University of Zagreb, Faculty of Food Technology and Biotechnology, Pierottijeva 6, HR-10000 Zagreb,

Croatia

${ }^{2}$ Belarussian National Technical

University, Power Plant Construction and Engineering Services Faculty, Nezavisimosti Ave. 150, BY-220013 Minsk, Belarus

BBelarussian National Technical University, Mining Engineering and Engineering Ecology Faculty, Nezavisimosti Ave. 65, BY-220013 Minsk, Belarus

Received: 2 October 2017 Accepted: 26 February 2018

\footnotetext{
*Corresponding author:

Phone: +38514605290 ;

Fax: +38514836424 ;

E-mail: bsantek@pbf.hr
}

ORCID IDs: 0000-0002-3572-5752

(Bušić), 0000-0002-9577-4556 (Kundas), 0000-0003-2638-8157 (Morzak)

0000-0002-3857-9818 (Marđetko), 0000-0002-5935-6672 (Ivančić Šantek), 0000-0002-9062-1673 (Komes), 0000-0001-9583-534X (Šantek)

\begin{abstract}
SUMMARY
Biodiesel and biogas are two very important sources of renewable energy worldwide, and particularly in the EU countries. While biodiesel is almost exclusively used as transportation fuel, biogas is mostly used for production of electricity and heat. The application of more sophisticated purification techniques in production of pure biomethane from biogas allows its delivery to natural gas grid and its subsequent use as transportation fuel. While biogas is produced mostly from waste materials (landfills, manure, sludge from wastewater treatment, agricultural waste), biodiesel in the EU is mostly produced from rapeseed or other oil crops that are used as food, which raises the 'food or fuel' concerns. To mitigate this problem, considerable efforts have been made to use non-food feedstock for biodiesel production. These include all kinds of waste oils and fats, but recently more attention has been devoted to production of microbial oils by cultivation of microorganisms that are able to accumulate high amounts of lipids in their biomass. Promising candidates for microbial lipid production can be found among different strains of filamentous fungi, yeast, bacteria and microalgae. Feedstocks of interest are agricultural waste rich in carbohydrates as well as different lignocellulosic raw materials where some technical issues have to be resolved. In this work, recovery and purification of biodiesel and biogas are also considered.
\end{abstract}

Key words: biodiesel, biogas, microbial lipids, transesterification, anaerobic digestion, recovery and purification

\section{INTRODUCTION}

Non-renewable fossil raw materials (oil, coal and natural gas) are still the most used sources of energy and chemicals, where approximately three quarters are used for generation of power and heat and nearly one quarter is used as fuel for transportation. Only few percents of fossil raw materials are used to produce chemicals and polymer materials (1).

Many important factors like vulnerable dependence of global economy on fossil raw materials, political issues connected with important oil-producing countries, emission of greenhouse gases and climate changes have moved the focus of many governments to explore alternatives of using renewable energy sources $(2,3)$.

During the last few decades the production and usage of biofuels (biodiesel, biogas and bioethanol fuel) has raised considerable interest as an appropriate means for partial substitution of fossil fuels. Biofuels derived from plant-based biomass are considered as renewable and represent an environmentally acceptable energy source, thus offering the potential to reduce and replace consumption of fossil fuels in great extent (4). Trends in production and use of biodiesel and biogas will be considered here in detail.

\section{BIODIESEL}

The total use of agricultural land for biofuel production has reached 71 million ha, of which biodiesel makes $24 \%$ and bioethanol $62 \%(5,6)$. The biodiesel physicochemical properties are very close to those of diesel, and consequently biodiesel or its blends can be used in diesel engines with a few or no modifications. The most commonly used blend 
is B20, a 1:5 mixture of biodiesel and petroleum diesel. Mark B100 implies pure biodiesel, which can be blended at any level with petroleum diesel, and its higher flash point makes it a safer fuel to use, handle and store using the existing diesel tanks and equipment.

Compared to petroleum diesel, biodiesel has a higher cetane number. It also contains about 10 oxygen atoms in different fatty acids present in this fuel and no aromatic compounds at all. As a consequence, biodiesel has lower emission of hydrocarbons and carbon monoxide. Also, the carbon atoms in biodiesel do not originate from organic deposits in the Earth's crust. They are derived from present-day atmospheric carbon dioxide that was fixed by photosynthesis in oil-rich plants. Therefore, carbon dioxide produced by combustion of biodiesel is usual part of ongoing carbon cycle on Earth and thereby has much lower impact on greenhouse gas emission. The greenhouse gas emission of biodiesel (B100) is 4.5-fold lower than of gasoline, and 3-fold lower than of petroleum diesel (7). Although the $\mathrm{NO}_{\mathrm{x}}$ levels of biodiesel are slightly higher than those of petroleum diesel, biodiesel is believed to be more environmentally friendly because its use can significantly reduce the net carbon emissions and global warming $(7,8)$.

Biodiesel production from vegetable oils has been known since 1853, when scientists E. Duffy and J. Patrick succeed in producing biodiesel from these feedstocks (9). Rudolph Diesel, the inventor of the diesel engine, studied different fuels (e.g. powdered coal to peanut oil) and used peanut oil to fuel one of his engines at the Paris Exposition of 1900. The first oil crisis in the 20th century (1970s) brought up the use of vegetable oils as an alternative to the petroleum for biodiesel production (9). Vegetable oils are renewable, available, portable and biodegradable, they have high heat content, and low content of sulphur and aromatic compounds. The used vegetable oils are extremely viscous, with viscosities ranging from 10 to 20 times higher than of petroleum diesel. This is the major problem for their use in compression ignition engines. Therefore, they had to be modified for use as diesel fuel (10). One of the most common methods used to reduce oil viscosity in the biodiesel industry is transesterification of vegetable oil or animal fat with an alcohol with or without the use of a catalyst (11).

Biodiesel can be produced from different feedstocks and their choice is mostly related to the climate and geographical position of the production place. Hence, rapeseed and sunflower oils are mostly used in Europe; soybean oil is dominant in the United States, canola oil in Canada, while palm oil prevails in tropical countries (12). Since all these oils are used as food, their use for biofuel production has raised the 'food versus fuel' dispute. They are regarded as first generation biodiesel feedstock. The second generation biodiesel feedstock is derived from non-edible sources, e.g. from pongamia, jatropha, karanja, as well as microalgae and other microorganisms. Waste frying oil (13) and waste from slaughterhouses (e.g. fat, blood, bones, ligament trimmings, dead animals, dead placentas, etc.; 14-16) and rendering industry (e.g. tallow, meat and bone meals; 17 ) can also be classified in that category.

It is important to point out that the cost of biodiesel from the first generation biodiesel feedstock is currently $30 \%$ higher than of petroleum-based diesel (7). Furthermore, it is estimated that $60-80 \%$ of the biodiesel production cost stems from the cost of raw materials. All this makes use of low-cost second generation biodiesel feedstock a very attractive alternative.

In 2013, 28.9 billion litres of biodiesel were produced globally (5). Global biodiesel production is expected to reach 39 billion litres by 2024, corresponding to a $27 \%$ increase from 2014 (Fig. 1; 5). The European Union is the major biodiesel producer. USA, Brazil, Argentina, Indonesia and Thailand along with the EU together produce $85 \%$ of all biodiesel worldwide.

Production
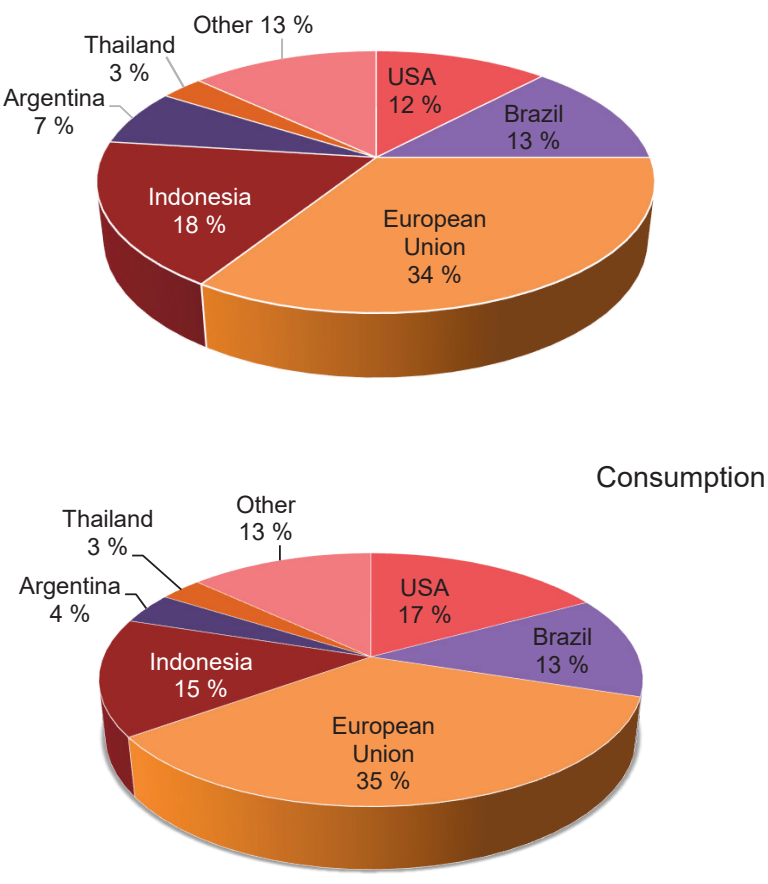

Fig. 1. Predictions of the world biodiesel production and consumption in 2024 (5)

Biodiesel is the most important biofuel in Europe. It makes nearly $80 \%$ of the market for transport biofuels (18). The most intensive market growth was in period 2006 to 2009. In that period market capacity almost quadrupled but then the growth was slowing down from 2010 to 2012, and in 2013 and 2014 , the capacity decreased by two percent each year. EU biodiesel production capacity is now expected to remain fairly flat at around 25 billion litres (18). Germany, France and Benelux countries are the major producers in the EU. The use of biodiesel, however, has increased from $45 \%$ in 2013 to 50 $\%$ in 2014 due to higher domestic production and lower imports (18). 
The major biodiesel feedstock in the EU is rapeseed oil. In 2012 it took $66 \%$ share but in 2014 its use dropped to 55 $\%$ as a consequence of higher palm oil and recycled waste frying oil use (18). Palm oil is the second raw material for biodiesel production in Benelux, Spain, Finland and France. The soybean oil is used in Spain, France, Germany, Portugal and Italy. The use of soybean and palm oil in conventional biodiesel is however limited, mainly because of their viscosity and winter operability. However, these obstacles can be circumvented by using rapeseed oil, soybean oil, and palm oil feedstock mix. Animal fats are used mostly in Germany and the UK. Sunflower oil comprises $3 \%$ of the total raw materials for biodiesel production and it is mainly used in France and Greece, while cottonseed and pine oil are used in Greece and Sweden, respectively (18).

EU biodiesel consumption reached its peak in 2011, but it declined in 2012 and 2013. Regarding the biodiesel consumption, France, Germany, Italy and the UK were the leaders in 2014 (18). They consumed $58 \%$ of total EU-28 biodiesel.

\section{PRODUCTION OF BIODIESEL FROM VEGETABLE OILS}

There are four possible ways to use oils and fats for diesel fuel: (i) direct blending, (ii) pyrolysis (thermal cracking), (iii) emulsification (microemulsions), and (iv) transesterification (19).

Direct use of oils and fats (in particular) in diesel engines would produce serious damage due to high viscosity, free fatty acid content, acidity, gum formation, oxidation and polymerization during storage and combustion, lubricating oil thickening, etc. (20).

Biodiesel obtained with pyrolysis and microemulsion methods is related to the incomplete combustion due to a low cetane number. Therefore, transesterification (or alcoholysis) remains at this moment the most convenient method for biodiesel production from vegetable oils and fats $(21,22)$, and it will be addressed in the following sections.

\section{Transesterification as a method of biodiesel production}

In transesterification triglycerides from vegetable oils and animal fats react with an alcohol in the presence of a strong acid or base. In this reaction the ester bonds between fatty acids (FAs) and -OH groups of glycerol break down and free fatty acids (FFAs) make new ester bonds with alcohol molecules present in transesterification mixture. At the end of reaction the mixture of fatty acids, alkyl esters and glycerol remains (23).

Methanol, ethanol, propanol, butanol and amyl alcohol can be used in transesterification, but methanol and ethanol are predominantly used. Fatty acid methyl esters (FAME) are produced in the presence of methanol, and fatty acid ethyl esters (FAEE) in the presence of ethanol. Both esters are used as biodiesel (11). Process efficiency of transesterification depends on several factors like the type of catalyst, temperature, alcohol to oil ratio, water and free fatty acid content, etc. (24).
Alcohol and triglycerides in oils and fats are not miscible enough to establish a single phase mixture. Thus, the multiphasic nature of the reaction mixture results in insufficient contact between reactants and consequently in very slow transesterification reaction. The use of catalysts can resolve this problem by facilitating the contact between reactants and consequently increasing the reaction rates and biodiesel yield (25).

Catalysts can be classified as homogeneous or heterogeneous. Homogeneous catalysts act in the same liquid phase as the reactants, while heterogeneous catalysts are usually solids that act in a different phase from the reactants. In addition, both can be either acidic or alkaline-based compounds (22). Base-catalysed reaction is better for oils with lower amount of FFAs, whereas acid-catalysed reaction is more convenient for oils having higher FFA content (26).

\section{Homogeneous catalytic transesterification}

Most widely used acids in homogenous catalytic transesterification are sulfuric acid, sulfonic acid, hydrochloric acid, organic sulfonic acid, ferric sulphate, etc. but the first three are usually favoured due to their strong acidity and low cost (27). Acidic catalysts are not sensitive to FFA content in the oil. This prevents side reactions like saponification and consequently results in the high-quality glycerol as byproduct. However, homogeneous acid catalytic transesterification is very sensitive to the presence of water, even at mass fraction of $0.1 \%$ in the reaction mixture, while $5 \%$ water stops the reaction almost completely (28). Homogeneous base catalysts (mostly alkaline metal alkoxides and hydroxides, or carbonates of sodium or potassium) are abundantly used for industrial transesterifications (20). Sodium or potassium hydroxides are mostly used due to their solubility in methanol, forming sodium or potassium methoxides that are actual catalytic agents for transesterification reaction (22). Homogeneous base catalysts are widely used because they provide modest operation conditions, high catalytic activity, and are widely available at modest costs (29). The processes can be carried out at low temperature and pressure (333-338 K and 140-420 kPa, respectively) with low catalyst mass fractions (0.5-2 \%) (30). Yields of biodiesel ranging from 94 to $99 \%$ are usually achieved when using sodium or potassium hydroxide at mass fractions from 0.5 to $1 \%$, methanol to oil ratio of $6: 1$, and temperatures of $45-80^{\circ} \mathrm{C}$. Under these conditions vegetable oils are completely transesterified in several hours (31).

However, the recovery of products and catalysts requires demanding procedures because of the homogenous phase of the mixture. This makes the process impractical and economically unattractive. Besides this, base catalysts react with FFAs normally present in the oil, and therefore unwanted byproducts are formed such as soap (32), which spoils the catalyst and decreases the ester yield, but also prevents successful glycerol separation from biodiesel (33). Therefore, the FFA content in oil must be as low as possible (less than $0.5 \%$ ) to avoid saponification (13). 
The transesterification of high FFA oils can also be achieved by employing a two-step process. In the first step, an acid-catalysed process is carried out, where esterification of the FFAs to FAMEs takes place, while the second step comprises base-catalysed transesterification (34). It has also been reported that a two-step process can also be achieved using alkaline catalysis in both steps. Increase of $10 \%$ of yield was recorded using a two-step alkaline catalysis of a feedstock containing $4 \%$ FFAs (35).

\section{Heterogeneous catalytic transesterification}

Heterogeneous base catalysts are materials like hydrotalcites and zeolites, which contain alkaline oxides or alkaline earth metals supported over large surface area (27). The possible advantages of the heterogeneous processes are higher yields of biodiesel, higher purity of glycerol, lower costs of catalyst and maintenance. However, the energy consumption and costs are considerably higher (20). Comparison between homogenous and heterogeneous catalytic transesterification shows that heterogeneous process is characterised by extreme reaction conditions. The $95 \%$ yield of biodiesel can be achieved by using $\mathrm{MgO}, \mathrm{CaO}$ and $\mathrm{TiO}_{2}$ catalysts at temperatures up to $200^{\circ} \mathrm{C}$ (36).

The Esterfip- $\mathrm{H}$ heterogeneous catalyst process is commercially used for biodiesel production (27). It does not require catalyst recovery nor aqueous treatment steps and results in high biodiesel yields and salt-free glycerol with $98 \%$ purity compared to homogeneous catalysed process, where less than $80 \%$ glycerol purity can be achieved.

Heterogeneous solid acid catalysts have also been used in many industrial processes. Main advantages are insensitivity to FFA content, elimination of purification step, easy separation of the catalyst, and smaller corrosion problem (20). Some of frequently studied solid acid catalysts are zinc stearate $/ \mathrm{SiO}_{2^{\prime}}, \mathrm{MoO}_{3} / \mathrm{ZrO}_{2^{\prime}}, \mathrm{WO}_{3} / \mathrm{ZrO}_{2^{\prime}}, \mathrm{WO}_{3} / \mathrm{ZrO}_{2}-\mathrm{Al}_{2} \mathrm{O}_{3^{\prime}}, \mathrm{MoO}_{3} /$ $\mathrm{SiO}_{2}, \mathrm{TPA} / \mathrm{ZrO}_{2}$ and zinc ethanoate $/ \mathrm{SiO}_{2}(27)$.

However, the use of heterogeneous solid base catalysts seems to be more acceptable for industrial application due to the simplification of production and purification processes, the decrease in the amount of basic wastewater, the downsizing of process equipment, and the reduction of environmental impact and process costs (37). Also, it was found that solid base catalysts are more active than solid acid catalysts (38). Developments of heterogeneous catalysts for biodiesel production have been extensively studied in many works $(22,27,37,39)$. CaO is the most often applied solid base catalyst because of the following advantages: long catalyst life, high activity, moderate reaction conditions and cheap natural calcium isolation sources (e.g. egg shells or mollusc shells) (22). There are reports on the use of ultrasonic technology to improve the mass transfer between the two immiscible liquids in a heterogeneous system on a laboratory scale $(40,41)$.

\section{Enzymatic catalytic transesterification}

Enzyme-catalysed transesterification reactions have been extensively studied. The use of enzymes like lipases provides numerous environmental and economic advantages such as: (i) use of mild reaction temperatures, (ii) high selectivity and specificity of trans/esterification, (iii) broader substrate range due to the ability to esterify both glyceride-linked and non-esterified fatty acids in one step, (iv) use of lower alcohol to oil ratios, ( $v$ ) avoidance of side reactions (no foam), easier separation and product recovery due to the production of a glycerol side stream with minimal impurities and water content, (vi) elimination of treatment costs associated with recovery of chemical catalysts, (vii) enzyme biodegradability and environmental acceptability, and (viii) opportunity for enzyme reuse and improved stability through enzyme immobilization (7). However, there are some drawbacks mostly related to the higher production costs, lower reaction rates, enzyme inhibition and loss of activity (typically within 100 days of operation). Despite these disadvantages, enzyme-catalysed process used for biodiesel production is nowadays considered as an environmentally friendly alternative having good opportunity to be highly commercialized when new, less expensive and more efficient biocatalysts are available $(7,42)$, especially with implementation of recombinant DNA technology (43).

Also, the pretreatment of lipases can have a positive influence on enhanced productivity and regeneration of enzyme activity (44). Namely, pretreatment of Rhizopus oryzae lipase with soybean oil before immobilization increased the lipase activity 20 times in comparison to non-treated lipase (45).

Lipases like triacylglycerol lipase (EC 3.1.1.3) are responsible for hydrolysis of triglycerides (TG) composed of long-chain fatty acids to glycerol and fatty acids $(46,47)$. On the other hand, esterases (e.g. EC 3.1.1.1, carboxyl ester hydrolases) prefer to hydrolyze only triglycerides composed of short-chain fatty acids (less than six C atoms). Both lipases and esterases belong to the class of hydrolases (EC 3.1.x.x). Lipases can be classified based on their origin to plant, animal or microbial lipases (7). However, for biodiesel production the most widely used are microbial lipases produced by filamentous fungi, yeasts and bacteria. Among them, the most frequently used enzyme sources are from orders of Candida, Pseudomonas and Rhizopus (7). The use of high quality enzymes results in conversions above $90 \%$. The origin of a specific lipase has a considerable impact on the optimal parameters for its application. Optimal temperatures vary between 30 and $50{ }^{\circ} \mathrm{C}$ and consequently reaction times could also be significantly different. For example, $8 \mathrm{~h}$ were needed for immobilized Pseudomonas cepacia lipase to conduct transesterification of jatropha oil with ethanol, but it took $90 \mathrm{~h}$ for the same enzyme in free form to transesterify soybean oil with methanol (48). Hence, besides the origin of the lipase, many other parameters influence the efficiency of enzymatic process (e.g. reaction temperature, water activity, free vs. immobilized enzyme, alcohol to oil ratio, choice of alcohol, etc.). These parameters have considerable impact on the maximum biodiesel yield, reaction time and enzyme lifetime (48). 
Selected strains of Mucor miehei, Rhizopus oryzae, Candida antarctica and Pseudomonas cepacia are regarded as major lipase-producing organisms (49). The main problem for using soluble enzymes lies in the fact that they are usually delivered in stabilized water solutions (with added preservative for the inhibition of microbial growth, e.g. benzoate, and with stabilizer to prevent enzyme denaturation, e.g. glycerol or sorbitol) (50). As already mentioned, water is a chemical contaminant in transesterification reaction. Thus to mitigate this obstacle, the enzyme preparation can be freeze-dried to remove the water, but this imposes new difficulties such as reduced enzyme activity, allergenicity of enzyme powder and inability of enzyme recovery and reuse (50).

Enzyme immobilization is the process of attaching enzymes to a solid supporting material by chemical or physical means (51). Lipase stability in the biodiesel production can be significantly increased by using adequate immobilization technique. Immobilization provides better operational stability in biodiesel production and reusability (52). A number of techniques and carriers are available for the immobilization of enzymes, and their choice depends on the nature of the enzyme and substrate and the type of reaction. For industrial application, support materials are selected based on the flow properties, low cost, non-toxicity and maximum biocatalyst loading while retaining the desirable flow characteristics, operational durability, availability and ease of immobilization (7). Standard immobilization methods that can be used in enzyme-catalysed transesterification are adsorption, covalent attachment, entrapment and cross-linkage (53). High biodiesel yields ranging from 95-100\% have been reported by using immobilized lipases from Pseudomonas cepacia, Thermomyces lanuginosus and Candida antarctica on different oils (sunflower, canola, etc.) and alcohols (54-56). Very high stability of reused immobilized lipases (almost no loss in activity after 200 cycles) has been reported (56).

Protein-coated microcrystals (PCMCs) and cross-linked enzyme aggregates (CLEAs) are also promising immobilization methods (57). PCMCs are water-soluble micron-sized particles, which are coated with the biocatalyst(s). They are formed by a one-step process where simultaneous dehydration and immobilisation of the protein on the micro-crystal surface takes place (57). CLEAs are formed by cross-linking of enzyme crystals. Because of uniform solvent-filled channels in the entire solid microporous body of the crystal, CLEAs are highly active. Therefore, they are more stable, active and enantioselective than their corresponding solubilized form (58). Several reports on successful application of these two immobilization methods for biodiesel production could be found in literature (59-63). However, immobilized enzymes are much more expensive than free enzymes (50).

In an attempt to avoid the complex enzyme recovery and purification requirements for immobilization of free (extracellular) lipase, the immobilization of whole microbial cells containing intracellular or membrane-bound lipase has been extensively studied in order to develop less expensive source of immobilized biocatalyst for biodiesel production (7). For that purpose readily available industrial cultures could be used and preparation of immobilized whole cells is much cheaper than production of immobilized enzymes. Consequently, this can significantly reduce the cost of transesterification $(7,64,65)$.

The frequently used bioreactors for enzymatic biodiesel production are batch stirred tank reactor (STR) and packed bed reactors (PBR). In STR, the enzyme (free or immobilized) is dispersed in the reaction mixture by agitation, whereas in the PBR, the immobilized enzyme is packed into a column. Both bioreactor types can operate in continuous mode and this reduces operational costs. The continuous PBR is superior to the batch PBR due to automated control and operation, reduced labour costs, stable operating conditions, and easy product quality control. Other bioreactor configurations include fluid beds, expanding bed, recirculation membrane reactors, and static mixers (7).

\section{Non-catalytic transesterification}

Due to several disadvantages of catalyst-assisted transesterification reactions, a research for development of efficient non-catalytic reactions gained some attention. Two non-catalytic transesterification processes have been reported so far: the so-called BIOX (or co-solvent) process and the supercritical alcohol process (20).

The non-catalysed transesterification is very slow because of low solubility of methanol in oil. By using a co-solvent that is soluble in both methanol and oil, this problem could be mitigated. With this regard, tetrahydrofuran was chosen as possible co-solvent because it has a low boiling point that is close to methanol, thus enabling operation at rather low temperature $\left(30^{\circ} \mathrm{C}\right)(20)$. In a single-phase two-step continuous process at relatively low pressure and temperature both TGs and FFAs are successfully transformed to biodiesel. However, due to the hazardous and toxic nature of tetrahydrofuran, it has to be completely removed from both glycerol and biodiesel (20). It was reported, however, that both tetrahydrofuran and excess alcohol can be recovered in a single step (66).

In a supercritical alcohol process, a non-catalytic transesterification is enforced by high pressure and temperature (25). The supercritical conditions produce the decrease of alcohol dielectric constant, thus increasing the solubility of TGs in alcohol, which consequently accelerates the transesterification reaction rate as well. This technology has several advantages: (i) insensitivity to the presence of FFA and water in reaction mixture, (ii) fast reaction rates, (iii) continuous operation mode, and (iv) water washing is not needed in product recovery step (13). However, the disadvantages of supercritical alcohol process are requirements for high pressure (20-60 $\mathrm{MPa})$ and temperature $\left(250-400^{\circ} \mathrm{C}\right)$ with high ratios of methanol to oil (around 42:1), which augment the production costs (20). Successful application of supercritical methanol technology has been reported for palm oil transesterification in 
a batch-type reactor system (67) and for coconut and palm kernel oil in a continuous transesterification process (68). Furthermore, the catalyst-free conversion of rapeseed oil into fatty acid butyl esters by microwave irradiation was also studied, and high efficiency of rapeseed oil transesterification with 1-butanol was observed only under near-critical or supercritical conditions (69).

\section{Isolation and purification of biodiesel}

Crude biodiesel obtained after the transesterification is a mixture of FAMEs, glycerol, excess alcohol, and impurities of soap formed during the reaction, unrecovered catalyst, water, as well as unreacted mono-, di- and triglycerides (70). After a transesterification is completed, crude biodiesel is left for 8-24 $\mathrm{h}$ for glycerol to settle. Separation of glycerol is carried out mostly in decantation funnels, or by centrifugation, followed by the removal of excess alcohol by distillation or evaporation under atmospheric pressure or vacuum. Then, the biodiesel is subjected to washing step in order to remove traces of catalyst, soap, glycerol and other impurities. The usual washing methods are: stir or mix washing, mist washing, bubble washing, and washing by stirring (70). Both single or combination of two or more washing methods can be applied to obtain prescribed biodiesel purity. There are also other washing methods like washing with phosphoric acid, silica gel, magnesium silicates or ion-exchange resins to absorb impurities (70-72).

After washing, biodiesel still contains traces of water that must be removed because of corrosion and gelation problems which can damage the diesel engine. It is recommended to reduce water content in final biodiesel to less than $500 \mathrm{mg} / \mathrm{L}$ (70). The water removal can be done by settling, by heating and by usage of chemicals. Heating of biodiesel (e.g. by agitating at $110-120^{\circ} \mathrm{C}$ for about $20 \mathrm{~min}$, or $90-110^{\circ} \mathrm{C}$ under vacuum for $20 \mathrm{~min}$ to $1 \mathrm{~h}$ ) also helps to remove remaining alcohol (70). Drying by using drying agents such as anhydrous sodium sulphate and magnesium sulphate or 4-Å molecular sieves could also be conducted. The purest biodiesel is obtained by distillation. Various fractions of FAMEs are collected at 90-240 ${ }^{\circ} \mathrm{C}$ under vacuum or atmospheric pressure $(70,73)$.

\section{PRODUCTION OF BIODIESEL FROM MICROBIAL LIPIDS}

Concerns about global shortage of agricultural land for growing human population and competition of biofuel production with production of food for precious arable land have raised interest for producing microbial lipids (also called microbial oils, single-cell lipids or single-cell oils) as non-food feedstock for biodiesel production (74). Microbial oils have similar TG and FA composition to that of vegetable oils. Also, the production of microbial oils has some technical advantages, such as short production life cycle, less labour required, lower dependence on season and climate, and easier scale-up process (75).

\section{Microorganisms and feedstocks for lipid production}

Microbial oils are produced by many so-called oleaginous microorganisms that could be found among fungi (moulds and yeasts), microalgae and bacteria (76). An oleaginous microorganism is capable of storing over $20 \%$ of 'oil' in dry mass in the form of lipids, primarily as TAGs and FAs (77). However, not all of them are suitable for biodiesel production (78). Main oleaginous microorganisms employed for microbial oil production are reported in a work of Subramaniam et al. (79). Many oleaginous microorganisms (moulds, yeasts and bacteria) produce lipids from organic substrates rich in sugars or starch (first generation of microbial oil production) or from lignocellulosic materials (second generation). Consequently, varieties of energy crops and waste materials from agriculture and industry (mainly food industry, wood and paper industry, etc.) have been investigated as possible feedstocks (79). Oleaginous microalgae, as autotrophic microorganisms, can produce lipids directly from $\mathrm{CO}_{2}$ and this is considered to be the third generation of microbial oil production.

Oil accumulation in microbial cells during growth on organic substrates is a feature of unbalanced metabolism. The growth of new cells with minimal levels of lipid will occur if all required nutrients are present in the growth medium. But, if the carbon source is added in excess, then some other nutrient in the growth medium will become limiting and the cell growth will be stopped. Usually, the limiting nutrient is nitrogen, normally in the form of $\mathrm{NH}_{4}{ }^{+}(80)$, therefore the lipid accumulation within the cell can be easily regulated by adjusting the $\mathrm{C}: \mathrm{N}$ ratio in the nutrient medium. With high $\mathrm{C}: \mathrm{N}$ ratio the cells continue to assimilate the carbon source but the nitrogen starvation will stop the protein and nucleic acid synthesis and then the cell metabolism will direct the excess carbon towards lipid biosynthesis and deposition of lipids in discrete lipid bodies within a cell as a storage material of carbon and energy $(81,82)$. Therefore, the maintenance of optimal C:N ratio in the nutrient medium is the most important parameter of the microbial oil production.

Among monosaccharides, glucose is the most common carbon source, but fructose, mannose and galactose are also suitable for growth of certain species. Besides monosaccharides, disaccharides (sucrose and lactose), and polysaccharides (e.g. starch) are also considered as effective carbon sources. Sugar beet molasses $(83,84)$ and sugar cane molasses $(85,86)$ have been explored as carbon sources for microbial oil production. Cassava, potato, Jerusalem artichoke and sorghum also have high content of fermentable oligo- and polysaccharides. They are studied as alternative feedstocks for microbial oil production, particularly because they are capable of growing on the land with low maintenance requirements and sustainable in a long term. However, the competition with food production and economic considerations still need to be resolved (87).

Many industrial byproducts, food and other organic wastes, can also be utilized as carbon sources for lipid production, since they are low-cost feedstocks, and abundant 
and available from many industries. However, due to their heterogeneous composition, and possible contamination with toxic compounds, their use for production of microbial oils has to be considered carefully. Large amounts of byproduct glycerol remain after transesterification reaction in the biodiesel industry, and thus the potential of glycerol as carbon substrate for microbial oil production has been extensively studied $(82,87)$.

Lignocellulose-containing feedstocks are most often used as a carbon source for microbial oil production, which could be regarded as a potential second generation biodiesel. The production of microbial oil from lignocellulosic biomass requires three major steps: (i) hydrolysis of lignocellulose into fermentable sugars, (ii) microbial conversion of sugars to oil deposited in microbial cells, and (iii) generation of biodiesel from microbial oil (88). Oleaginous yeast and fungal strains are the main investigated organisms in cellulosic conversion to lipids. Lipid biosynthesis is a slower process than ethanol fermentation. However, being the aerobic process, it can transform xylose to lipids without problems that have to be resolved in lignocellulosic bioethanol fermentation. There are still many challenges in culturing oleaginous strains on lignocellulosic hydrolysates: (i) the presence of various sugars in hydrolysate, (ii) limited concentrations of sugars, (iii) the requirement for nitrogen-rich commercial enzymes (cellulases and hemicellulases), which aggravates the control of C:N ratio, and (iv) generation of inhibitors (furfural, hydroxymethyl furfural, phenolics, etc.) during pretreatment step (89). Reported theoretical yields are $0.32 \mathrm{~g}$ per $\mathrm{g}$ of sugar from glucose and 0.34 g per $\mathrm{g}$ of sugar from xylose (90), but the achieved practical yields are near $0.22 \mathrm{~g}$ of lipid per $\mathrm{g}$ of glucose (81).

Optimal temperatures for the growth of oleaginous microrganisms are: $25-35{ }^{\circ} \mathrm{C}$ for algae, $25-30{ }^{\circ} \mathrm{C}$ for yeasts, and $20-28{ }^{\circ} \mathrm{C}$ for moulds, and optimal pH range typically 6-9 for algae and 4-7 for yeasts and moulds (89).

Oleaginous yeasts are single-cell fungi that can accumulate more than $40 \%$ (by mass) oil and some yeast strains can reach as much as $70 \%$ (by mass) under controlled conditions. They can be cultivated on various sugars (glucose, mannose, fructose, galactose, xylose, arabinose, sucrose or lactose) and glycerol. They grow at high growth rates, and their oil has similarTG profile as vegetable oils, although this differs from strain to strain (79).

Yeast strains of Cryptococcus albidus, Lipomyces lipofera, Lipomyces starkeyi, Rhodosporidium toruloides, Rhodotorula glutinis, Trichosporon pullulans and Yarrowia lipolytica can accumulate oils under controlled cultivation conditions. Among FAs found in yeast TGs, the dominant are myristic, palmitic, stearic, oleic, linoleic and linolenic acid. Oils from these yeasts have been successfully transformed to biodiesel either by enzymatic or chemical catalysts (91). Rhodosporidium sp., Rhodotorula sp. and Lipomyces sp. were found to accumulate as high as $70 \%$ lipids in their dry biomass. The most efficient oleaginous yeast, Cryptococcus curvatus, can accumulate up to $90 \%$ (by mass) lipids. For comparison, Saccharomyces cerevisiae and the food yeast Candida utilis can hardly accumulate more than 5-10\% (by mass) lipids (78).

The biomass of some oleaginous filamentous fungi can be produced with nearly $80 \%$ of oil on dry mass basis. Their oils contain a high concentration of $\gamma$-linolenic acid (GLA) and arachidonic acid, thus they are considered for production of these high-value products, which are more profitable than biodiesel (79). For instance, lipids produced by Mortierella isabellina contain $20 \%$ linoleic acid, $20 \%$ palmitic acid and $50 \%$ oleic acid. M. isabellina has been proposed to be used for production of high-value fatty acids for pharmaceuticals, as well as for biodiesel production (92). Similar promissing results with Mortierella alliacea strain YN-15 were also reported (93).

The lipids produced by bacteria are usually much different from other microbial oils and only a small number of bacteria can produce oils that can be used for biodiesel production. Hence, bacteria are mainly used for production of some special lipids like polyunsaturated fatty acids and some branched chain fatty acids (91). However, species such as Mycobacterium, Streptomyces, Rhodococcus and Nocardia can accumulate TAGs at high concentrations. The Actinomycetes group of bacteria can accumulate up to $70 \%$ lipids when grown on glucose with high C:N ratio $(79,94)$. It was also reported that Gordonia sp. DG can accumulate $72 \%$ lipids at the end of stationary phase, while maximum lipid content accumulated by R. opacus PD630 was $80 \%$ at the beginning of the stationary phase (86).

For the production of biodiesel, only oleaginous microorganisms with a high content of stearic acid (C18:0) and oleic acid (C18:1) could be targets of interest, since they mimic the properties of high-value oils for biodiesel production (78). For that purpose Neurospora crassa was genetically modified by deleting glycogen synthase and enhancing acetyl-CoA synthase, which results in more than 2-fold FA accumulation on the lignocellulosic biomass pretreated with dilute acid (95). This shows that the potential of genetic and metabolic engineering improvements of the microbial oil production is certainly promising and still far from being extensively explored.

Microalgae are regarded as 'miniature sunlight-driven biochemical factories' and they are considered as a potential source of third generation biodiesel. They are capable of producing large amounts of lipids and hydrocarbons in the presence of sunlight and carbon dioxide from flue gases (96). In general, $\mathrm{CO}_{2}$ volume fraction from 2 to $15 \%$ is proved to be suitable for maintaining a favourable growth rate and lipid yield (87). Moreover, they are able to provide several different types of renewable biofuels, like biodiesel, photobiologically produced bio-hydrogen, and methane produced by anaerobic digestion of the algal biomass (78). Many microalgal species exist in single cells or simple clusters of a few cells, which enables them to grow fast and accumulate more oil. Some fast-growing species could be harvested continuously on a daily basis, thus enabling high biomass productivity per area (97). Many microalgae are rich in omega 3 and omega 6 fatty acids, as well as in essential amino acids, like leucine, 
isoleucine, valine, etc. More than $80 \%$ TGAs can be accumulated in some microalgae, with a fatty acid profile rich in $\mathrm{C} 16$ and C18 FAs (98). The average lipid content varies between 1 and $70 \%$, but can reach as high as $90 \%$ of dry mass under specific conditions (99). However, microalgae need much longer time than oleaginous yeast or fungi to achieve considerable yields of lipids (at least two weeks). Therefore, better selection and/ or development is needed of highly productive oleaginous microalgae that are able to rapidly capture and utilize $\mathrm{CO}_{2}$, are resistant to the toxic components such as $\mathrm{SO}_{x}$ and $\mathrm{NO}_{\mathrm{x}}$ in the flue gases, and have good adaptability to temperature and light fluctuations (87).

Different methods of recovery of lipids from algae are available including the conventional ones where lipids are extracted by solvents and then converted into fatty acid methyl esters (FAME) via transesterification. The complexity of lipid extraction from algae is the limiting step of this process. Therefore, innovative methods are developed such as pressurized fluid extraction method (100) or in-situ transesterification of biomass into biodiesel $(101,102)$. The pressurized fluid extraction method was successfully used for polyunsaturated fatty acid (PUFA) extraction from Nannochloropsis oculata, where the maximum fatty acid yield of $16.7 \%$ by mass was observed during algal biomass extraction with ethanol (100).

The in-situ transesterification of biomass to biodiesel is characterized by lipid extraction and transesterification in one step. Therefore, lipid extraction step is avoided compared to the conventional lipid extraction process, which has a positive impact on the industrial process costs. This method was used for biodiesel production from the biomass of Botryococcus braunii in conventional batch reactor (CBR) and reflux extraction reactor (RER) (101). In the RER, biodiesel yield of $80.6 \%$ by mass was observed, which is considerably higher than in the CBR ( $64.5 \%$ by mass). The efficiency of this method depends on the temperature, catalyst dosage, and particle size of dry algal biomass as well as on cosolvent use in the reaction mixture. On the basis of the obtained results, it was observed that the increase of FAME yield was related to the decrease of biomass particle size and increase of co-solvent proportion in reaction system. Furthermore, addition of co-solvent also causes the increase of saturated and monounsaturated methyl ester content and improves its stability $(101,102)$.

\section{Bioprocess modes for microbial lipid production}

For microbial oil production, different bioprocess modes have been applied, such as batch, fed-batch and continuous mode. The mode of production is an important parameter for optimizing the lipid production both technically and economically (82). Most studies have been carried out using batch cultivation (79,81,82,103-105).

Repeated batch cultivations were studied by Veloso et al. (106) using Phaeodactylum tricornutum, Chiu et al. (107) with Nannochloropsis oculata, Hsieh and Wu (108) with Chlorella sp., and Feng et al. (109) with Chlorella vulgaris.
Fed-batch mode is a convenient way for producing biomass in high concentration by intermittent or continuous feeding of nutrients to avoid substrate inhibition or catabolite repression (79). The process is conducted in two steps. The first step corresponds to a pure growth phase with a C:N ratio of feeding medium optimized for fast proliferation of microbial cells. The second step is conducted with a high C:N ratio (nitrogen limitation), which enforces lipid accumulation in already grown cells $(82,110,111)$.

There are only few reports on microbial oil production by continuous mode. In a continuous mode fresh nutrient medium is continuously supplied to a well-stirred bioreactor and a spent medium from the bioreactor is simultaneously withdrawn to keep net reactor volume constant. In continuous mode, lipid accumulation strongly depends on the dilution rate and C:N ratio of the nutrient medium (82). For example, in a continuous culture of Yarrowia lipolytica, cultivated on raw glycerol in nitrogen-limited continuous cultures, $\mathrm{Pa}$ panikolaou and Aggelis (112) obtained lipid content of $43 \%$ by mass, but with low volumetric productivity of $1.2 \mathrm{~g} /\left(\mathrm{L}^{\circ} \mathrm{h}\right)$. Furthermore, during continuous culture of Trichosporon oleaginosus on glucose-containing medium with different $\mathrm{C}: \mathrm{N}$ ratio, the cell lipid content was over $50 \%$ dry cell mass with total lipid accumulation productivity of $0.67 \mathrm{~g} /\left(\mathrm{L}^{\circ} \mathrm{h}\right)$ (113). Different studies of microbial lipid production by different microbial strains from various raw materials are presented in Table 1 (111,114-130).

\section{Recovery of microbial lipids before transesterification}

First step in lipid recovery involves harvesting microbial cells from spent cultivation medium. After that cells can be either dried or disrupted before lipid extraction.

For cell harvesting from broth, following methods can be used: centrifugation, filtration, coagulation or flocculation (89). Dry cell biomass after harvesting results in higher lipid yields after extraction - more than extraction of disrupted wet cell biomass (lower yield). Cell disruption can be done by bead milling, high-pressure homogenization, ultrasonication, microwave treatment, enzymatic hydrolysis of cell walls, and acid hydrolysis. All this techniques are expensive, but so is the drying. The cell harvesting is also expensive process (especially when cell concentration is low), therefore a lot of improvements are needed to render the recovery of the microbial lipids economical (89).

Lipid extraction is done with organic solvents (chloroform, methanol or hexane), usually by Bligh and Dyer or Soxhlet method (89). To avoid energy-intensive solvent recovery, extraction can be done with supercritical liquids $\left(\mathrm{CO}_{2}\right.$ or $\left.\mathrm{N}_{2}\right)$. Dry or wet cell biomass can also be used in transesterification. In these cases, extraction and transesterification occur simultaneously. Oil from microalgae has been recovered by hydrothermal liquefaction and this technology is also proposed for lignocellulose-based lipid biorefineries (89). 
Table 1. Different studies of microbial lipids production from various feedstocks

\begin{tabular}{|c|c|c|c|c|c|}
\hline Species & Carbon source & Cultivation mode & $w($ lipid $) / \%$ & Note & Reference \\
\hline Aspergillus oryzae & Sugar cane bagasse & Batch & 19.6 & $\begin{array}{l}\text { Dilute acid pretreatment } \\
\text { Enzymatic hydrolysis }\end{array}$ & 114 \\
\hline Chlorella pyrenoidosa & $\mathrm{CO}_{2}$ & Batch & 26.8 & $50 \% \mathrm{CO}_{2}$ & 115 \\
\hline \multirow[t]{3}{*}{ Cryptococcus sp. } & Glucose & Batch & 63.5 & - & 111 \\
\hline & Glucose & Fed-batch & 63.5 & - & \\
\hline & Corncob & Fed-batch & 61.3 & $\begin{array}{l}\text { Acid pretreatment } \\
\text { Enzymatic hydrolysis }\end{array}$ & \\
\hline \multirow[t]{5}{*}{ Cryptococcus albidus } & Acetic acid & Batch & 25.8 & - & 116 \\
\hline & Sodium acetate & Batch & 24.5 & & \\
\hline & Ethanol & Batch & 24.9 & & \\
\hline & Volatile fatty acids & Batch & 25.1 & & \\
\hline & Ammonium acetate & Batch & 24.1 & & \\
\hline \multirow[t]{3}{*}{ Lipomyces starkeyi } & Glucose & Batch & 23.7 & - & 117 \\
\hline & Potato starch & Batch & 40.3 & & \\
\hline & Corncob & Batch & 47.0 & $\begin{array}{l}\text { Commercial product of } \\
\text { corncob acid hydrolysate }\end{array}$ & 118 \\
\hline \multirow[t]{5}{*}{ Mortierella isabellina } & Xylose & Batch & 64.5 & - & 119 \\
\hline & Wheat straw & Batch & 53.0 & Dilute acid pretreatment & 120 \\
\hline & Rice hull & Batch & 64.3 & Acid hydrolysis & 121 \\
\hline & $\begin{array}{l}\text { Corn stover } \\
\text { Switchgrass } \\
\text { Miscanthus } \\
\text { Giant reed }\end{array}$ & Batch & $\begin{array}{l}24.8 \\
35.6 \\
32.2 \\
21.2\end{array}$ & $\begin{array}{c}\text { Dilute acid pretreatment } \\
\text { Enzymatic hydrolysis } \\
\text { Glucose and xylose as carbon } \\
\text { sources }\end{array}$ & 122 \\
\hline & Corn stover & Batch & 30.0 & $\begin{array}{c}\text { Dilute acid and alkali pretreatments } \\
\text { Enzymatic hydrolysis } \\
\text { Mixture of glucose, } \\
\text { xylose and acetate as carbon } \\
\text { sources }\end{array}$ & 123 \\
\hline Nannochloropsis sp. & $\begin{array}{l}\text { Municipal } \\
\text { wastewater and } \\
\text { seawater }\end{array}$ & Batch & 59.9 & $15 \% \mathrm{CO}_{2}$ aeration & 124 \\
\hline \multirow[t]{2}{*}{ Rhodococcus opacus PD630 } & Loblolly pine & Batch & 24.8 & $\begin{array}{c}\text { Autohydrolysis } \\
\text { (hot water pretreatment) }\end{array}$ & 125 \\
\hline & Sweetgum & & 28.6 & & \\
\hline \multirow{2}{*}{$\begin{array}{l}\text { Rhodococcus opacus } \\
\text { DSM1069 }\end{array}$} & Loblolly pine & & 28.3 & & \\
\hline & Sweetgum & & 17.5 & & \\
\hline \multirow[t]{3}{*}{ Rhodosporidium toruloides } & Jerusalem artichoke & Batch & 43.3 & J. artichoke extract & 126 \\
\hline & & Fed-batch & 40.1 & J. artichoke extract & \\
\hline & & Fed-batch & 56.5 & $\begin{array}{c}\text { J. artichoke hydrolysate } \\
\text {-acid hydrolysis }\end{array}$ & \\
\hline \multirow[t]{4}{*}{ Rhodosporidium toruloides } & Corn stover & Batch & 58.67 & Dilute acid and alkali pretreatments & 127 \\
\hline & & $\begin{array}{l}\text { Dissolved oxygen- } \\
\text {-stat fed-batch }\end{array}$ & 59.81 & & \\
\hline & & Pulse fed-batch & 61.54 & & \\
\hline & & Online fed-batch & 58.76 & & \\
\hline \multirow[t]{2}{*}{ Rhodotorula glutinis } & Glycerol & Batch & 52.91 & - & 128 \\
\hline & & Fed-batch & 60.7 & & \\
\hline Rhodotorula mucilaginosa & Sugar cane bagasse & Batch & 11 & $\begin{array}{l}\text { Dilute acid pretreatment } \\
\text { Enzymatic hydrolysis }\end{array}$ & 114 \\
\hline \multirow[t]{2}{*}{ Scenedesmus obliquus } & $\mathrm{CO}_{2}$ & Batch & 24.40 & $50 \% \mathrm{CO}_{2}$ & 115 \\
\hline & $\mathrm{CO}_{2}$ & Batch & 38.9 & $10 \% \mathrm{CO}_{2}$ & 129 \\
\hline \multirow[t]{3}{*}{ Thamnidium elegans } & Glucose & Batch & 69.5 & - & 130 \\
\hline & Fructose & & 70.4 & & \\
\hline & Sucrose & & 70.0 & & \\
\hline
\end{tabular}




\section{BIOGAS}

The biogas production is a well-known technology that brings many benefits, both economic and environmental, because biogas is a renewable energy source that comes from cheap and environmentally friendly recycling of organic waste and it lowers the greenhouse gas emission. The biogas production is also a sanitation process that reduces pathogen microorganisms in organic waste, removes odours and flies and produces an organic fertilizer that brings economic benefits for the farmers (131). The availability at low costs and ability to use the broad spectrum of feedstocks makes biogas a very usable fuel that can be used to produce heat, steam, electricity, hydrogen or even as transportation fuel (132).

Biogas is generated from organic material by the action of microorganisms in the absence of air in a process called anaerobic digestion or methanogenesis. The nature of the raw materials and anaerobic digestion conditions has considerable impact on the chemical composition of biogas. Raw biogas mainly contains methane in the amount of $40-75 \%$, and carbon dioxide ranging from 15 to $60 \%$ (133). After the removal of $\mathrm{CO}_{2}$ and other impurities, which are however present in trace amounts, the final product is called biomethane, typically containing $95-97 \% \mathrm{CH}_{4}$ and $1-3 \% \mathrm{CO}_{2}$ (133). Biomethane can replace natural gas as a feedstock for producing chemicals and materials (132).

The highest biogas yield is correlated with fat content in broth, but long retention time is required for fat conversion due to their poor bioavailability. In case of carbohydrates and proteins, much faster conversion rates are observed with lower gas yields (132). The amount of produced gas depends on several factors such as temperature, $\mathrm{pH}$ and alkalinity, hydraulic and organic loading rates, toxic compounds, substrate type, and total solid and volatile solid content (134). Strong lignified organic substances (e.g. wood) are not suitable for biogas production because their anaerobic decomposition is very slow (132).

Anaerobic digestion is mostly associated with the treatment of animal manure (cows, pigs, chicken, etc.) and sewage sludge. However, in order to achieve higher biogas yields, today majority of biogas facilities digest manure with the addition of cosubstrates (e.g. energy crops, organic wastes from agriculture-related industries, food waste, municipal biowaste from households, etc.) (132). In total, agricultural residues and animal manure represent together more than $80 \%$ of the potential feedstocks for biogas production (132).

In 2014, biogas production (by volume) increased to approx. 58.7 billion $\mathrm{Nm}^{3}$ (1.27 EJ; average energy density factor of 21.6 MJ/Nm 3 ; 0.3584 PW.h) (135). Europe and Asia dominate in biogas production, where Germany and China are leading producers, followed by the USA (135). In Europe, $49.8 \%$ of the world biogas is produced, followed by $31.9 \%$ in Asia, $16.7 \%$ in Americas and $1.6 \%$ in the rest of the world (135). The biogas sector in Europe is very diverse. Germany and UK are the two largest biogas producers in the EU. Germany generates $92 \%$ of its biogas from agricultural crops and residues, while UK, Bulgaria, Estonia and Portugal are more oriented towards landfill and sewage sludge gas. Other countries usually rely on a more various feedstock combinations. In Europe, the majority of the biogas is used to generate electricity and/or heat. According to the European Biogas Association (EBA) statistical report 2017 (136), the biogas production has greatly increased since 2011: production rose from 752 GW.h in 2011 to 17264 GW.h in 2016. In Europe alone in 2016 biogas production increased $40 \%$ (4971 GW.h). In 2016, the largest increase of biogas production was observed in Germany ( $900 \mathrm{GW} \cdot \mathrm{h})$, France (133 GW.h) and Sweden (78 GW.h). Some of large-scale gas production facilities purify the biogas to biomethane, which could be delivered into the natural gas grid or used as transportation fuel. The number of these facilities is growing, particularly in Germany and Austria. In 2015, 97 tonnes of oil equivalent (TOE) (1 $\mathrm{TOE}=41.87 \mathrm{GJ}=11.63 \mathrm{MW} \cdot \mathrm{h}$ ) in Sweden, 30 TOE in Germany and 0.5 TOE in Austria of biogas was used as transportation fuel (137). The USA is the main biogas producer in both Americas with production of 8.48 billion $\mathrm{Nm}^{3}$. In the USA, 2200 biogas plants (mostly wastewater treatment facilities) are in operation. However, the biogas production has been slow in the last few years although the US Department of Energy estimates that the USA has a potential to build up over 13000 plants (producing over 40 TW.h of electricity). According to the global statistic data, the biogas production has significantly increased since 2000 . In the period 2000-2014, the average annual growth of biogas production was $11.2 \%$ (135). The prediction for European biogas production in 2017 and 2018 is further increase of biogas production for 3-5\% (in 2018 it is expected to reach the value of $16985 \mathrm{kTOE} ; 1 \mathrm{kTOE}=11.63 \mathrm{GW} \cdot \mathrm{h}=41.87 \mathrm{GJ})$. However, it is expected that landfill and sewage sludge biogas will stagnate, but biogas production from agricultural raw materials will be enlarged (137). Similar situation will probably be on the global level too.

\section{ANAEROBIC DIGESTION TECHNOLOGY FOR BIOGAS PRODUCTION}

Anaerobic digestion (AD) is a biological process in which organic matter is decomposed by a range of microorganisms producing biogas under oxygen-free conditions (138). The AD can be divided into four steps (hydrolysis, acidogenesis, acetogenesis/dehydrogenation and methanation). The process starts with hydrolysis of organic material (decomposition of complex organic polymers to simple soluble monomers) by extracellular enzymes which are produced by hydrolytic microbes. In this process, complex carbohydrates, proteins and lipids are hydrolysed to simple sugars, amino acids, glycerol and fatty acids, respectively. These small molecules are then converted via fermentation by acidogenic bacteria to a mixture of volatile fatty acids (VFAs) and alcohols. After that, acetogenic bacteria further convert the VFAs to acetate, carbon dioxide and hydrogen. These compounds are substrates for the final, methane-producing step called methanation (or methanogenesis; 139). 
$A D$ is a very complex biochemical process that requires a great number of bacterial species in a consortium in order to hydrolyse and ferment organic material to biogas. Most of these species are strict anaerobes such as Clostridia, Bacteriocides and Bifidobacteria, but facultative anaerobes like Streptococci and Enterobacteriaceae could also be present (132). The hydrogen-producing acetogenic bacteria include bacteria like Acetobacterium woodii and Clostridium aceticum (132). Methanogenic bacteria produce methane from acetate, hydrogen and carbon dioxide. All methanogenic bacteria are capable of forming methane from $\mathrm{CO}_{2}$ and hydrogen, but only a few species (Methanosarcina barkeri, Methanococcus mazei and Methanotrix soehngenii) can degrade acetate into $\mathrm{CH}_{4}$ and $\mathrm{CO}_{2}$ (132). Since all the microbes in the consortium are closely linked with each other, process can be actually achieved in two stages (140). Among the four microbial groups, methanogenic bacteria grow most slowly and they are the most sensitive to changes in environmental conditions. This makes methanogenesis a rate-limiting step of the entire AD process. However, in degradation of lignocellulosic feedstock, due to its recalcitrant structure, hydrolysis could become a limiting step. For that reason, a pretreatment step of lignocellulosic materials is required prior to anaerobic digestion, in order to achieve more efficient microbial breakdown of cellulose and hemicellulose, which in the end will result in increased biogas yield (139).

The digestion is carried out at mesophilic $\left(35-42^{\circ} \mathrm{C}\right)$ or thermophilic $\left(45-60^{\circ} \mathrm{C}\right)$ temperatures (132). Temperature fluctuations negatively affect the bioprocess, thus temperature maintenance is necessary for a large scale operation. Biosynthesis of methane occurs in a relatively narrow $\mathrm{pH}$ interval (6.5-8.5) with an optimum between 7.0 and 8.0. It could be strongly inhibited at $\mathrm{pH}$ below 6.0 or above 8.5. Ammonia accumulation causes $\mathrm{pH}$ increase due to protein degradation, while VFA accumulation is related to the $\mathrm{pH}$ decrease. VFAs are a key intermediate in the process and when in high concentrations, they can inhibit methanogenesis.

Molecules containing carbon, nitrogen, phosphorus and sulphur are regarded as macronutrients. The growth of microbial biomass in $A D$ is very low, thus a nutrient ratio is kept around C:N:P:S=600:15:5:1, respectively (132). Such macronutrient composition favours high metabolic activity towards methane production. Trace elements like cobalt, iron, selenium, nickel, molybdenum and tungsten are considered as micronutrients that are important for optimal physiological state of the microbial consortium which conducts the AD process (132). The addition of micronutrients is crucial for AD when energy crops are used as the only substrate for biogas production (132). The required concentrations of micronutrients are extremely low, ranging from 0.05 to $0.06 \mathrm{mg} / \mathrm{L}$. The only exception is iron, because its level is kept in a range of 1-10 $\mathrm{mg} / \mathrm{L}(131,141)$.

There are two common bioprocess types of AD (132): (i) wet (or liquid anaerobic digestion, i.e. LAD) and (ii) dry (or solid-state anaerobic digestion, i.e. SS-AD) bioprocess. Different bioreactor configurations can be used in these bioprocesses, and they can be generally divided in three main groups: (i) conventional anaerobic bioreactors (anaerobic sequencing batch bioreactor, continuous stirred tank bioreactor, and anaerobic plug-flow bioreactor), (ii) sludge retention bioreactors (anaerobic contact bioreactor, internal circulation bioreactor, up-flow anaerobic sludge bed reactor, up-flow anaerobic solid-state bioreactor, anaerobic baffled bioreactor), and (iii) anaerobic membrane reactors (anaerobic filter bioreactor, anaerobic fluidized bed reactor, and expanded granular sludge blanket; 142).

LAD (or wet) bioprocesses are operated with less than $10 \%$ total solids in the broth to allow good stirring in tank digesters (132). SS-AD (or dry) bioprocesses are operated in the range of $15-35 \%$ total solids. Wet bioprocesses are more convenient to be operated continuously, and they are widely used in the agricultural sector (132). LAD bioprocesses have a faster reaction rate and shorter retention time, but SS-AD are generally thought to be more advantageous due to smaller reactor volume required, and this implicates less energy input and easier effluent handling (143).

Vertical continuous stirred tank reactor (CSTR) is the most common reactor configuration employed for LAD (132). The broth homogeneity in the CSTR can be achieved by mechanical, hydraulic or pneumatic mixing. However, mechanical stirrers (slow or fast rotation) are used in around $90 \%$ of biogas plants. Fast rotating stirrers operate several times per day, while slow rotating stirrers operate more or less continuously. The mixing in the CSTR also enables contact of microorganisms with the substrate, rising up of gas bubbles and maintaining constant optimal temperature in the whole bioreactor. In order to prevent sedimentation and floating layers, three or four stirrers are required (132).

When energy crops are used, it is more convenient to carry out the $A D$ in a two-stage bioreactor system in series. In the first stage the bioreactor had high substrate loading and in the second low substrate loading, which handles the digestate from the first stage (132). In two-stage bioreactor system, hydrolysis and methanogenesis take place in both bioreactors. However, the appliance of two-stage system to separate hydrolysis in the first bioreactor can be advantageous due to the fact that ideal $\mathrm{pH}$ for hydrolysis (5.5-6.5) and methanogenesis (6.8-7.2) is different $(132,144)$. This configuration mode is more often applied for industrial and municipal organic waste, as well as for solid manure (132). For AD of energy crops, hydraulic retention times need to be prolonged for several weeks. For that purpose, loading rates of organic dry matter in wet bioprocesses are kept low (2-4 kg/( $\mathrm{m}^{3} \cdot$ day $)$ ). Most AD facilities are operated with mesophilic microorganisms, and only few apply thermophilic conditions (145).

Dry AD bioprocesses carried out as monofermentation of energy crops usually apply batch mode of operation combined with percolation of liquid phase instead of mechanical mixing in the so-called leach bed process. The solid substrate is loaded in portions and inoculated with remains of previous 
batch (146). During this AD bioprocess, water is dispersed over the substrate and recycled in order to regulate substrate moisture and temperature as well as to perform inoculation. After $A D$ is finished, usually in 3 or 4 weeks, the digestate is discharged to start a new batch. Three or more bioreactors have to work in parallel mode to assure constant and permanent biogas production. Produced biogas yields are comparable to wet bioprocess $(132,147)$. Methane yields can be increased by the use of the additional second stage methanogenic bioreactor combined with the leach bed bioprocess (148). Continuous dry AD bioprocesses could also be applied for substrates containing more than $25 \%$ dry matter (149). For that purpose, horizontal mechanically mixed bioreactors or vertical plug flow bioreactors can be used. These bioreactor configurations are well-known from anaerobic treatment of municipal solid waste (150). Vertical bioreactors are mixed by the substrate flow from the top to the bottom. At the bioreactor top the fresh substrate feed is mixed with outlet digestate from the bottom. Maintainig the optimal ratio of digestate to fresh feed keeps the accumulation of VFAs low, thus enabling higher loading rates of organic dry matter (compared to wet fermentation), which can reach up to $10 \mathrm{~kg} /\left(\mathrm{m}^{3}\right.$.day) (132).

In a study of Brown et al. (151), methane production with different lignocellulosic raw materials (corn stover, wheat straw, switchgrass, leaves, waste paper, maple and pine) was assessed under liquid anaerobic digestion (LAD) and solid-state anaerobic digestion (SS-AD). The authors did not find significant difference in methane yield between LAD and SS-AD, except for waste paper and pine. Zhu et al. (152) examined co-digestion of soybean processing waste (SPW) and hay in SS-AD process. The highest methane yield of $258 \mathrm{~L} /$ $\mathrm{kg}$ volatile solids was observed when using SPW/hay ratio of 75:25 and feedstock/effluent ratio of 3, which was 148 and $50 \%$ higher than when using SPW or hay alone, respectively. The CSTR and up-flow anaerobic sludge bed (UASB) reactors were used for evaluation of the potential of wheat straw hydrolysate for biogas production (153). In UASB reactor, methane yields were up to $267 \mathrm{~mL} / \mathrm{g}$ of chemical oxygen demand (COD; removal of $72 \%$ ) when working at an organic loading rate (OLR) of $2.8 \mathrm{~g}$ of COD/(L.day), but with only $10 \%$ (by volume) hydrolysate. Authors also reported that maximum volume fraction of hydrolysate should not exceed $25 \%$. Furthermore, improved methane yield of $219 \mathrm{~mL} / \mathrm{g}$ of COD (COD removal of $72 \%$ ) was observed during co-digestion of hydrolysate with pig manure (1:3 ratio by volume). Results from that study showed that anaerobic digestion of wheat straw hydrolysate as a sole substrate was feasible both in CSTR and UASB reactors.

Chen et al. (154) conducted experiments in submerged anaerobic membrane bioreactor with forward osmosis membrane (FO-AnMBR) for the treatment of synthetic wastewater. Obtained results pointed out that the FO-AnMBR process can successfully remove more than $96 \%$ of organic carbon, nearly $100 \%$ of total phosphorus and $62 \%$ of ammoniacal nitrogen.
Bo et al. (155) proposed a new upgraded biogas production process where they combined microbial electrolysis cell (MEC) and anaerobic digestion in a single-chamber reactor. They documented that in the MEC-AD coupled system, $\mathrm{CO}_{2}$ generated from $A D$ could be in situ reduced on the anode to additional $\mathrm{CH}_{4}$ by the hydrogenotrophic methanogens. Authors achieved methane content in excess of $98 \%$, while the $\mathrm{CH}_{4}$ yield was increased 2.3 times. Also, the COD removal rate was increased three times and carbon recovery was increased by $56.2 \%$.

\section{Biogas production from lignocellulosic materials}

The main energy crops currently used on a commercial scale for biogas production are sugar and starch crops. Among them, sugar beet, corn (grain) and potatoes are the most intensively studied, but many other less conventional starchy crops with potential for biogas utilization have been reported too (138).

Recently lignocellulosic materials have gained more interest as potential candidates for biogas production via AD, but a large-scale implementation has not been widely adopted, mainly because of the complicated structure of the cell walls of lignocellulosic plants, which makes them resistant to hydrolysis by microbial attack. Therefore, the pretreatment of lignocellulosic material is essential step to achieve high process yields $(139,156)$.

Mirahmadi et al. (157) studied biogas production from softwood spruce and hardwood birch by using alkaline $(\mathrm{NaOH})$ pretreatment under mild operating conditions. The pretreatment resulted in 83 and $74 \%$ improvement in methane production from birch and spruce, respectively. O-Thong et al. (158) studied biogas production during thermophilic anaerobic co-digestion of oil palm empty fruit bunches (EFB) and palm oil mill effluent (POME). The highest methane yield of $392 \mathrm{~mL} / \mathrm{g}$ of added volatile solids (corresponding to $82.7 \mathrm{~m}^{3}$ of $\mathrm{CH}_{4}$ per $\mathrm{m}^{3}$ of mixture) can be expected in co-digestion of treated EFB ( $\mathrm{NaOH}$ presoaking and hydrothermal treatment) and POME at the ratio of 6.8:1 on volatile solids basis (corresponding to $1: 1$ on volume basis). The EFB biodegradability was increased for $46 \%$ compared to the untreated EFB (158). Different pine tree wastes (needle leaves, branches, cones and bark) were pretreated with $8.0 \%$ (by mass) $\mathrm{NaOH}$ at $0{ }^{\circ} \mathrm{C}$ for 60 min or $100^{\circ} \mathrm{C}$ for $10 \mathrm{~min}$ in order to improve the biogas production efficiency (159). The effect of rice straw pretreatment with ammonium hydroxide and hydrogen peroxide on $A D$ was investigated by Song et al. (160). A combined dilute acid-thermal pretreatment was used for the conversion of sunflower oil cake into methane by mesophilic anaerobic digestion (161). Pretreatment of sunflower stalks with $\mathrm{HCl}$ or $\mathrm{FeCl}_{3}$ at $170{ }^{\circ} \mathrm{C}$ for $1 \mathrm{~h}$ increased methane production by 21 and 29 $\%$, respectively (162). Pretreatment of water hyacinth (Eichhornia crassipes) with ionic liquid and cosolvent (1-N-butyl-3-methylimidazolium chloride and dimethyl sulfoxide) removed $49.2 \%$ of the lignin and increased the biogas yield by $97.6 \%$ (105). N-methylmorpholine-N-oxide (NMMO), a cellulose solvent that decreases the cellulose crystallinity (163), was used 
for pretreatment of barley straw and forest residues (164). The optimal conditions resulted in 88 and $83 \%$ improvement of theoretical methane yields when using barley straw and forest residues, respectively. In other studies, digestibility of spruce, birch, rice, triticale straw, and forest residues was also enhanced by pretreatment with 85 or $75 \%$ NMMO at $120-130$ ${ }^{\circ} \mathrm{C}$, resulting in increased biogas yields (165-167). Biogas production from three lignocellulosic raw materials (winter rye straw, oilseed rape straw and faba bean straw) was studied in a work of Petersson et al. (168). These raw materials were pretreated by wet oxidation using parameters previously found to be optimal for corn stover pretreatment $\left(195^{\circ} \mathrm{C}, 15 \mathrm{~min}, 2\right.$ $\mathrm{g} / \mathrm{L}$ of $\mathrm{Na}_{2} \mathrm{CO}_{3}$ and oxygen pressure of $1.2 \mathrm{MPa}$ ).

Microwave-pretreated residual straw (barley, spring and winter wheat or oat) was examined for biogas production in a laboratory batch study, but the results showed that the microwave pretreatment of the straw did not improve AD performance (169). However, Jackowiak et al. (170) used microwave radiation for pretreatment of wheat straw, and found that it was able to enhance the methane yield by $28 \%$. Cesaro et al. (171) reported the use of sonolysis in anaerobic co-digestion with $24 \%$ methane yield improvement. Application of an extruder to increase the methane yield of barley straw in biogas production was studied by Hjorth et al. (172). Extrusion causes an increase in methane production throughout 90 days. Actually, the effect of extrusion on the cumulative methane production from straw was large after 28 days (70\%), but became statistically non-significant after 90 days.

The focus of biological pretreatment for enhancement of biogas production in $A D$ is mainly on use of enzymatic and fungal pretreatment, or pretreatment by microbial consortium (139). Zhao (143) studied the effect of fungal pretreatment by Ceriporiopsis subvermispora on methane yield from yard trimmings, and reported that it increased the methane yield up to $154 \%$ at moisture content of $60 \%$ and natural aeration. Moreover, wood-decaying fungus Auricularia auricula-judae for the decomposition of sweet chestnut (Castanea sativa) leaves and hay using anaerobic digestion was discussed in paper of Mackulak et al. (173). Authors revealed that the fungal pretreatment of the mixture of leaves and hay (at the ratio of 1:2) increased biogas production by $15 \%$ compared to untreated samples. Enhancement of methane production from sun-dried cassava residues by biological pretreatment using a constructed microbial consortium was documented by Zhang et al. (174). Their experiments in batch bioreactors at $55^{\circ} \mathrm{C}$ indicated maximum methane yield $(259.46 \mathrm{~mL}$ per $\mathrm{g}$ of volatile solids) in mixture of pretreated cassava residues and distillery wastewater during $12 \mathrm{~h}$ of pretreatment, which was $96.63 \%$ higher than the control. Usually, sterilization of lignocellulosic feedstock is not necessary when using a microbial consortium for pretreatment, which makes it advantageous over fungal pretreatment (139). Enzymatic pretreatment of lignocellulosic wastes, like sugar beet pulp and spent hops, to improve biogas production was evaluated by Ziemiński et al. (175). Enzymatic treatment of sugar beet pulp and spent hops results in an increase of total biogas yield for 19 and 13 $\%$, respectively. In general, most biological pretreatments are not as efficient as chemical ones, and their retention time is relatively high; thus for commercial production additional research is needed to address challenges in efficiency and production costs (139).

Residual algal biomass (after recovery of value-added products like pigments, lipids or bioactive compounds) could also be used for biogas production (176). The potential of residual algal biomass strongly depends on the algal species composition and the pretreatment process for recovery of high value products. However, it has to be pointed out that residual algal biomass can be directly used in biogas plant without drying process. Furthermore, residue from biogas production (digestate) is rich in nutrients (e.g. potassium, phosphates and minor mineral compounds), and therefore it can be used as green fertilizer in agriculture $(176,177)$.

\section{Biogas purification}

In contrast to liquid biofuels (biodiesel and bioethanol), a product separation step in anaerobic digestion is unnecessary, as the biogas evaporated off by itself from the liquid (138). Besides methane and carbon dioxide, raw biogas also contains trace amounts of other components such as water (5-10\%), hydrogen sulphide (0.005-2 \%), siloxanes (0-0.02 \%), halogenated hydrocarbons $(<0.6 \%)$, ammonia $(<1 \%)$, oxygen (0-1\%), carbon monoxide (<0.6\%) and nitrogen (0-2\%), and they might be inconvenient if not removed (133).

Different techniques are employed for biogas cleaning and upgrading. Condensation methods usually use demisters, cyclone separators or moisture traps (133). Drying methods, such as adsorption and absorption, are used to remove water in combination with foam and dust. Water condensation is usually a first step in a biogas cleaning for its mixing with natural gas or usage as transportation fuel. Water must be separated from biogas by adsorption or absorption at higher pressure. The most frequently used is adsorption on alumina or zeolites. For removal of $\mathrm{H}_{2} \mathrm{~S}$ from biogas, different techniques have been developed, such as air dosing to the biogas or iron chloride addition into the bioreactor (133). Other techniques employ adsorption on iron oxide and hydroxide pellets or on activated carbon, absorption in liquids, membrane separation, and less often biological filtration. However, to choose an appropriate technique for $\mathrm{H}_{2} \mathrm{~S}$ removal, the technique to remove $\mathrm{CO}_{2}$ from biogas should be considered first. $\mathrm{A} \mathrm{CO}_{2}$ removal technique could be absorption with amines but it needs an additional step of $\mathrm{H}_{2} \mathrm{~S}$ removal. At the end, $\mathrm{CO}_{2}$ removal from biogas is usually performed using physical or chemical $\mathrm{CO}_{2}$ absorption, pressure swing adsorption, vacuum swing adsorption, and membrane separation. In addition, it is possible to produce biomethane using cryogenic separation, by cooling and compressing the biogas. Subsequently, trace components like siloxanes, hydrocarbons, ammonia, oxygen, carbon monoxide and nitrogen can require extra removal steps, if not sufficiently removed by other treatment steps (133). 
Different adsorbents, like an activated carbon, a silica gel and zeolites were tested for $\mathrm{H}_{2} \mathrm{~S}$ removal for biogas conversion in a solid oxide fuel cell, where zeolite was the best adsorbent candidate (178). In a work of Micoli et al. (179), Cu and Zn modified $13 \mathrm{X}$ zeolites prepared by ion exchange or impregnation and activated carbon treated with $\mathrm{KOH}, \mathrm{NaOH}$ or $\mathrm{Na}_{2} \mathrm{CO}_{3}$ solutions were studied as $\mathrm{H}_{2} \mathrm{~S}$ sorbents for biogas purification for fuelling molten carbonate fuel cells. Unmodified and modified activated carbons were more effective $\mathrm{H}_{2} \mathrm{~S}$ sorbents than zeolites, where the activated carbons treated with $\mathrm{Na}_{2} \mathrm{CO}_{3}$ was the most effective sorbent.

Innovative application of microaeration directly in UASB reactor for the removal of hydrogen sulphide from synthetic brewery wastewater biogas was applied in a study of Krayzelova et al. (180). Authors gained reliable and stable removal efficiency in long-term operation, and in a microaerobic UASB reactor (UMSB), they obtained an average $73 \%$ efficiency of $\mathrm{H}_{2} \mathrm{~S}$ removal.

Dolejš et al. (181) studied the use of water-swollen membranes for the simultaneous removal of $\mathrm{CO}_{2}, \mathrm{H}_{2} \mathrm{~S}$ and $\mathrm{H}_{2} \mathrm{O}$ from biogas, and they successfully removed up to $82 \%$ (by volume) of $\mathrm{CO}_{2}$, and $77 \%$ (by volume) of $\mathrm{H}_{2} \mathrm{~S}$ from the feed stream at a pressure of $220 \mathrm{kPa}$. The separation of $\mathrm{CO}_{2}$ by clathrate hydrate formation with tetra- $n$-butylammonium bromide (TBAB) solution in the presence of 1-butyl-3-methylimida-

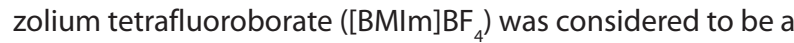
promising and economically feasible approach compared to the traditional techniques described in a work of Li et al. (182). The efficiency of water washing system for $\mathrm{CO}_{2}$ removal from biogas was studied by changing different process parameters such are liquid/gas ratio, pressure, temperature, and $\mathrm{CO}_{2}$ content (183). The most beneficial approach for reducing $\mathrm{CO}_{2}$ content at a constant gas inflow rate was to increase pressure (from 0.8 to $1.2 \mathrm{MPa}$ ) combined with a decrease of temperature. Under these conditions, $\mathrm{CO}_{2}$ removal could reach values from 24.4 to $83.2 \%$ when $\mathrm{CO}_{2}$ content in the simulated gas was $25-45 \%$.

\section{CONCLUSIONS}

On the basis of this consideration, it is obvious that biodiesel and biogas are very important renewable energy sources. Currently, biodiesel is mostly used as transportation fuel and biogas for production of electricity and heat. The main advantage of these two renewable energy sources lies in the fact that for their production, a relatively wide range of renewable raw materials can be used. Current worldwide biodiesel production is based on the oil crops and consequently it has a huge impact on the food market. Waste oils and fats or microbial lipid production from renewable raw materials (especially lignocellulosic biomass) have the highest potential to substitute oil crops in biodiesel production. Although microbial lipid production has many obstacles that need to be overcome, it has a great pontential for development of sustainable and environmentally friendly biodiesel production systems. Worldwide biogas production is based on the renewable waste materials and consequently it reduces negative impact on the environment. Biorefinery concept has to be utilized for biodiesel and biogas production systems in order to obtain more value-added products that could additionally enlarge environmental and economic sustainability of these bioprocesses.

\section{ACKNOWLEDGEMENTS}

This work was supported by the project Phoenix (H2020-MSCA-RISE project no. 690925) and the project 'Sustainable production of bioethanol and biochemicals from agricultural waste lignocelullosic raw materials' (Croatian Science Foundation No. 9158).

\section{REFERENCES}

1. Bhaskar T, Bhavya B, Singh R, Naik DV, Kumar A, Goyal HB. Thermochemical conversion of biomass to biofuels. In: Pandey A, Larroche C, Ricke SC, Dussap CG, Gnansounou $\mathrm{E}$, editors. Biofuels - Alternative feedstocks and conversion processes. Oxford, UK: Academic Press; 2011. pp. 5177.

https://doi.org/10.1016/B978-0-12-385099-7.00003-6

2. Cherubini F, Strømman AH. Principles of biorefining. In: Pandey A, Larroche C, Ricke SC, Dussap CG, Gnansounou $\mathrm{E}$, editors. Biofuels - Alternative feedstocks and conversion processes. Oxford, UK: Academic Press; 2011. pp. 3-24.

https://doi.org/10.1016/B978-0-12-385099-7.00001-2

3. Forster P, Ramaswamy V, Artaxo P, Berntsen T, Betts R, Fahey DW, et al. Changes in atmospheric constituents and in radiative forcing. In: Solomon S, Qin D, Manning $M$, Chen Z, Marquis M, Averyt KB, et al., editors. Climate change 2007: The physical science basis. Cambridge, UK: Cambridge University Press; 2007. pp. 129-234.

4. Khanal SK, editor. Anaerobic biotechnology for bioenergy production: Principles and applications. Ames, IA, USA: Wiley-Blackwell; 2008.

https://doi.org/10.1002/9780813804545

5. Kummamuru B. WBA global bioenergy statistics 2016. Stockholm, Sweden: World Bioenergy Association; 2016. Available from: www.worldbioenergy.org.

6. Huang GH, Chen F, Wei D, Zhang XW, Chen G. Biodiesel production by microalgal biotechnology. Appl Energy. 2010;87(1):38-46. https://doi.org/10.1016/j.apenergy.2009.06.016

7. Christopher LP, Kumar H, Zambare VP. Enzymatic biodiesel: Challenges and opportunities. Appl Energy. 2014;119:497-520. https://doi.org/10.1016/j.apenergy.2014.01.017

8. Ramadhas AS, Jayaraj S, Muraleedharan C. Biodiesel production from high FFA rubber seed oils. Fuel. 2005;84(4):335-40. https://doi.org/10.1016/j.fuel.2004.09.016 
9. Demirbas A. Recent developments in biodiesel fuels. Int J Green Energy. 2007;4(1):15-26. https://doi.org/10.1080/15435070601015395

10. Madras G, Kolluru C, Kumar R. Synthesis of biodiesel in supercritical fluids. Fuel. 2004;83(14-15):2029-33. https://doi.org/10.1016/j.fuel.2004.03.014

11. Demirbas A. Production of biofuels with special emphasis on biodiesel. In: Pandey A, editor. Handbook of plant-based biofuels. Boca Raton, FL, USA: CRC Press; 2009. pp. 45-54. https://doi.org/10.1201/9780789038746.ch4

12. Cao P, Dubé MA, Tremblay AY. High-purity fatty acid methyl ester production from canola, soybean, palm, and yellow grease lipids by means of a membrane reactor. Biomass Bioenergy. 2008;32(11):1028-36. https://doi.org/10.1016/j.biombioe.2008.01.020

13. Lam MK, Lee KT. Mixed methanol-ethanol technology to produce greener biodiesel from waste cooking oil: A breakthrough for $\mathrm{SO}_{4}{ }^{2-} / \mathrm{SnO}_{2}-\mathrm{SiO}_{2}$ catalyst. Fuel Process Technol. 2011;92(8):1639-45. https://doi.org/10.1016/j.fuproc.2011.04.012

14. Schober S, Seidl I, Mittelbach M. Ester content evaluation in biodiesel from animal fats and lauric oils. Eur J Lipid Sci Technol. 2006;108(4):309-14. https://doi.org/10.1002/ejlt.200500324

15. Koller M, Braunegg G. Biomediated production of structurally diverse poly(hydroxyalkanoates) from surplus streams of the animal processing industry. Polimery. 2015;60(5):298308.

https://doi.org/10.14314/polimery.2015.298

16. Shahzad K, Narodoslawsky M, Sagir M, Ali N, Ali S, Rashid $\mathrm{Ml}$, et al. Techno-economic feasibility of waste biorefinery: Using slaughtering waste streams as starting material for biopolyester production. Waste Manag. 2017;67:73-85. https://doi.org/10.1016/j.wasman.2017.05.047

17. Nebel BA, Mittelbach M. Biodiesel from extracted fat out of meat and bone meal. Eur J Lipid Sci Technol. 2006;108(5):398403. https://doi.org/10.1002/ejlt.200500329

18. EU Biofuels Annual 2015. GAIN report number NL5028. The Hague, The Netherlands: United States Department of Agriculture-Foreign Agriculture Service (USDA-FAS), Global Agricultural Information Network (GAIN); 2015. Available from: http://gain.fas.usda.gov/Recent\%20GAIN\%20Publications/ Biofuels\%20Annual_The\%20Hague_EU-28_7-15-2015.pdf.

19. Demirbas A. Biodiesel from waste cooking oil via base-catalytic and supercritical methanol transesterification. Energ Convers Manag. 2009;50(4):923-7. https://doi.org/10.1016/j.enconman.2008.12.023

20. Abbaszaadeh A, Ghobadian B, Omidkhah MR, Najafi G. Current biodiesel production technologies: $A$ comparative review. Energ Convers Manag. 2012;63:138-48. https://doi.org/10.1016/j.enconman.2012.02.027
21. Juan JC, Kartika DA, Wu TY, Hin TYY. Biodiesel production from jatropha oil by catalytic and non-catalytic approaches: An overview. Bioresour Technol. 2011;102(2):452-60. https://doi.org/10.1016/j.biortech.2010.09.093

22. Borges ME, Díaz L. Recent developments on heterogeneous catalysts for biodiesel production by oil esterification and transesterification reactions: A review. Renew Sust Energy Rev. 2012;16(5):2839-49.

https://doi.org/10.1016/j.rser.2012.01.071

23. Ma F, Hanna MA. Biodiesel production: A review. Bioresour Technol. 1999;70(1):1-15.

https://doi.org/10.1016/S0960-8524(99)00025-5

24. Ali Y, Hanna MA, Cuppett SL. Fuel properties of tallow and soybean oil esters. J Am Oil Chem Soc. 1995;72(12):1557-64. https://doi.org/10.1007/BF02577854

25. Tan KT, Lee KT, Mohamed AR. Production of FAME by palm oil transesterification via supercritical methanol technology. Biomass Bioenergy. 2009;33(8):1096-9. https://doi.org/10.1016/j.biombioe.2009.04.003

26. Schuchardt U, Sercheli R, Vargas RM. Transesterification of vegetable oils: A review. J Braz Chem Soc. 1998;9(1):199-210. https://doi.org/10.1590/S0103-50531998000300002

27. Atadashi IM, Aroua MK, Aziz ARA, Sulaiman NMN. The effects of catalysts in biodiesel production: A review. J Ind Eng Chem. 2013;19(1):14-26.

https://doi.org/10.1016/j.jiec.2012.07.009

28. Cerveró JM, Coca J, Luque S. Production of biodiesel from vegetable oils. Grasas Aceites. 2008;59(1):76-83. https://doi.org/10.3989/gya.2008.v59.i1.494

29. Kawashima A, Matsubara K, Honda K. Acceleration of catalytic activity of calcium oxide for biodiesel production. Bioresour Technol. 2009;100(2):696-700. https://doi.org/10.1016/j.biortech.2008.06.049

30. Lotero E, Goodwin Jr JG, Bruce DA, Suwannakarn K, Liu Y, Lopez DE. The catalysis of biodiesel synthesis. In: Spivey JJ, Rosley KM, editors. Catalysis, vol. 19. London, UK: RSC Publishing; 2006. pp. 41-83. https://doi.org/10.1039/978184-7555229-00041

31. Demirbas A. Progress and recent trends in biofuels. Prog Energy Combust Sci. 2007;33(1):1-18. https://doi.org/10.1016/j.pecs.2006.06.001

32. Tan KT, Lee KT. A review on supercritical fluids (SCF) technology in sustainable biodiesel production: Potential and challenges. Renew Sust Energ Rev. 2011;15(5):2452-6. https://doi.org/10.1016/j.rser.2011.02.012

33. Kondamudi N, Mohapatra SK, Misra M. Quintinite as a bifunctional heterogeneous catalyst for biodiesel synthesis. Appl Catal A. 2011;393(1-2):36-43.

https://doi.org/10.1016/j.apcata.2010.11.025

34. Aransiola EF, Betiku E, Ikhuomoregbe DIO, Ojumu TV. Production of biodiesel from crude neem oil feedstock and its emissions from internal combustion engines. Afr J Biotech- 
nol. 2012;11(22):6178-86.

https://doi.org/10.5897/AJB11.2301

35. Çaylı G, Küsefoğlu S. Increased yields in biodiesel production from used cooking oils by a two step process: Comparison with one step process by using TGA. Fuel Process Technol. 2008;89(2):118-22.

https://doi.org/10.1016/j.fuproc.2007.06.020

36. Singh AK, Fernando SD. Reaction kinetics of soybean oil transesterification using heterogeneous metal oxide catalysts. Chem Eng Technol. 2007;30(12):1716-20. https://doi.org/10.1002/ceat.200700274

37. Aransiola EF, Ojumu TV, Oyekola OO, Madzimbamuto TF, Ikhu-Omoregbe DIO. A review of current technology for biodiesel production: State of the art. Biomass Bioenergy. 2014;61:276-97.

https://doi.org/10.1016/j.biombioe.2013.11.014

38. Magalhães Antunes W, de Oliveira Veloso C, Assumpção Henriques C. Transesterification of soybean oil with methanol catalyzed by basic solids. Catal Today. 2008;133135:548-54.

https://doi.org/10.1016/j.cattod.2007.12.055

39. Kouzu M, Kasuno T, Tajika M, Sugimoto Y, Yamanaka S, Hidaka J. Calcium oxide as a solid base catalyst for transesterification of soybean oil and its application to biodiesel production. Fuel. 2008;87(12):2798-806.

https://doi.org/10.1016/j.fuel.2007.10.019

40. Ji J, Wang J, Li Y, Yu Y, Xu Z. Preparation of biodiesel with the help of ultrasonic and hydrodynamic cavitation. Ultrasonics. 2006;44:e411-4.

https://doi.org/10.1016/j.ultras.2006.05.020

41. Mootabadi H, Salamatinia B, Bhatia S, Abdullah AZ. Ultrasonic-assisted biodiesel production process from palm oil using alkaline earth metal oxides as the heterogeneous catalysts. Fuel. 2010;89(8):1818-25.

https://doi.org/10.1016/j.fuel.2009.12.023

42. Brun N, Babeau-Garcia A, Achard MF, Sanchez C, Durand F, Laurent $\mathrm{G}$, et al. Enzyme-based biohybrid foams designed for continuous flow heterogeneous catalysis and biodiesel production. Energy Environ Sci. 2011;4(11):2840-4. https://doi.org/10.1039/c1ee01295a

43. Akoh CC, Chang SW, Lee GC, Shaw JF. Enzymatic approach to biodiesel production. J Agric Food Chem. 2007;55(22):89959005.

https://doi.org/10.1021/jf071724y

44. Ozmen EY, Yilmaz M. Pretreatment of Candida rugosa lipase with soybean oil before immobilization on $\beta$-cyclodextrin-based polymer. Colloids Surf B Biointerfaces. 2009;69(1):58-62. https://doi.org/10.1016/j.colsurfb.2008.10.021

45. Lee DH, Kim JM, Shin HY, Kim SW. Optimization of lipase pretreatment prior to lipase immobilization to prevent loss of activity. J Microbiol Biotechnol. 2007;17(4):650-4.
46. Al-Zuhair S. Production of biodiesel by lipase-catalyzed transesterification of vegetable oils: A kinetics study. Biotechnol Progr. 2005;21(5):1442-8.

https://doi.org/10.1021/bp050195k

47. Bornscheuer UT. Microbial carboxyl esterases: Classification, properties and application in biocatalysis. FEMS Microbiol Rev. 2002;26(1):73-81. https://doi.org/10.1111/j.1574-6976.2002.tb00599.x

48. Fjerbaek L, Christensen KV, Norddahl B. A review of the current state of biodiesel production using enzymatic transesterification. Biotechnol Bioeng. 2009;102(5):1298-315. https://doi.org/10.1002/bit.22256

49. Gog A, Roman M, Toşa M, Paizs C, Irimie FD. Biodiesel production using enzymatic transesterification - Current state and perspectives. Renew Energ. 2012;39(1):10-6. https://doi.org/10.1016/j.renene.2011.08.007

50. Nielsen PM, Brask J, Fjerbaek L. Enzymatic biodiesel production: Technical and economical considerations. Eur J Lipid Sci Technol. 2008;110(8):692-700. https://doi.org/10.1002/ejlt.200800064

51. Spahn C, Minteer SD. Enzyme immobilization in biotechnology. Recent Pat Eng. 2008;2(3):195-200. https://doi.org/10.2174/187221208786306333

52. Al-Zuhair S, Hasan M, Ramachandran KB. Kinetics of the enzymatic hydrolysis of palm oil by lipase. Process Biochem. 2003;38(8):1155-63. https://doi.org/10.1016/S0032-9592(02)00279-0

53. Ganesan D, Rajendran A, Thangavelu V. An overview on the recent advances in the transesterification of vegetable oils for biodiesel production using chemical and biocatalysts. Rev Environ Sci Biotechnol. 2009;8:367-94. https://doi.org/10.1007/s11157-009-9176-9

54. Salis A, Pinna M, Monduzzi M, Solinas V. Biodiesel production from triolein and short chain alcohols through biocatalysis. J Biotechnol. 2005;119(3):291-9. https://doi.org/10.1016/j.jbiotec.2005.04.009

55. Dizge N, Keskinler B, Tanriseven A. Biodiesel production from canola oil by using lipase immobilized onto hydrophobic microporous styrene-divinylbenzene copolymer. Biochem Eng J. 2009;44(2-3):220-5. https://doi.org/10.1016/j.bej.2008.12.008

56. Li L, Du W, Liu D, Wang L, Li Z, Lipase-catalyzed transesterification of rapeseed oils for biodiesel production with a novel organic solvent as the reaction medium. J Mol Catal B Enzym. 2006;43(1-4):58-62.

https://doi.org/10.1016/j.molcatb.2006.06.012

57. Kreiner M, Fernandes JFA, O'Farrell N, Halling PJ, Parker MC. Stability of protein-coated microcrystals in organic solvents. J Mol Catal B Enzym. 2005;33(3-6):65-72. https://doi.org/10.1016/j.molcatb.2005.03.002

58. Cao L, van Langen $L$, Sheldon RA. Immobilised enzymes: Carrier-bound or carrier-free? Curr Opin Biotechnol. 
2003;14(4):387-94.

https://doi.org/10.1016/S0958-1669(03)00096-X

59. Kumari V, Shah S, Gupta MN. Preparation of biodiesel by lipase-catalyzed transesterification of high free fatty acid containing oil from Madhuca indica. Energy Fuels. 2007;21(1):368-72.

https://doi.org/10.1021/ef0602168

60. Sheldon RA, Schoevaart R, Van Langen LM. Cross-linked enzyme aggregates (CLEAs): A novel and versatile method for enzyme immobilization (a review). Biocatal Biotransformation. 2005;23(3-4):141-7. https://doi.org/10.1080/10242420500183378

61. Kartal F, Kilinc A. Crosslinked aggregates of Rhizopus oryzae lipase as industrial biocatalysts: Preparation, optimization, characterization, and application for enantioselective resolution reactions. Biotechnol Progr. 2012;28(4):937-45. https://doi.org/10.1002/btpr.1571

62. Kreiner M, Amorim Fernandes JF, O'Farrell N, Halling PJ, Parker MC. Stability of protein-coated microcrystals in organic solvents. J Mol Catal B Enzym. 2005;33(3-6):65-72. https://doi.org/10.1016/j.molcatb.2005.03.002

63. Gaur R, Gupta G, Vamsikrishnan M, Khare SK. Protein-coated microcrystals of Pseudomonas aeruginosa PseA lipase. Appl Biochem Biotechnol. 2008;151(2-3):160-6. https://doi.org/10.1007/s12010-008-8163-x

64. Ban K, Kaieda M, Matsumoto T, Kondo A, Fukuda H. Whole cell biocatalyst for biodiesel fuel production utilizing Rhizopus oryzae cells immobilized within biomass support particles. Biochem Eng J. 2001;8(1):39-43. https://doi.org/10.1016/S1369-703X(00)00133-9

65. Tamalampudi S, Talukder MR, Hama S, Numata T, Kondo A, Fukuda H. Enzymatic production of biodiesel from Jatropha oil: A comparative study of immobilized-whole cell and commercial lipases as a biocatalyst. Biochem Eng J. 2008;39(1):185-9. https://doi.org/10.1016/j.bej.2007.09.002

66. Demirbas A. Current technologies in biodiesel production. In: Demirbas A, editor. Biodiesel. London, UK: Springer; 2008. pp. 161-73. https://doi.org/10.1007/978-1-84628-995-8_7

67. Song ES, Lim JW, Lee HS, Lee, YW. Transesterification of RBD palm oil using supercritical methanol. J Supercrit Fluids. 2008;44(3):356-63. https://doi.org/10.1016/j.supflu.2007.09.010

68. Bunyakiat K, Makmee S, Sawangkeaw R, Ngamprasertsith S. Continuous production of biodiesel via transesterification from vegetable oils in supercritical methanol. Energy Fuels. 2006;20(2):812-7. https://doi.org/10.1021/ef050329b

69. Geuens J, Kremsner JM, Nebel BA, Schober S, Dommisse RA, Mittelbach M, et al. Microwave-assisted catalyst-free transesterification of triglycerides with 1-butanol under supercritical conditions. Energy Fuels. 2008;22(1):643-5. https://doi.org/10.1021/ef700617q

70. Huynh LH, Kasim NS, JuYH. Biodiesel production from waste oils. In: Pandey A, Larroche C, Ricke SC, Dussap CG, Gnansounou $E$, editors. Biofuels - Alternative feedstocks and conversion processes. Oxford, UK: Academic Press; 2011. pp. 375-96.

https://doi.org/10.1016/B978-0-12-385099-7.00017-6

71. Predojević ZJ. The production of biodiesel from waste frying oils: A comparison of different purification steps. Fuel. 2008;87(17-18):3522-8.

https://doi.org/10.1016/j.fuel.2008.07.003

72. Sabudak T, Yildiz M. Biodiesel production from waste frying oils and its quality control. Waste Manag. 2010;30(5):799803.

https://doi.org/10.1016/j.wasman.2010.01.007

73. Wang Y, Ou S, Liu P, Xue F, Tang S. Comparison of two different processes to synthesize biodiesel by waste cooking oil. J Mol Catal A Chem. 2006;252(1-2):107-12. https://doi.org/10.1016/j.molcata.2006.02.047

74. Fairley P. Introduction: Next generation biofuels. Nature. 2011;474: S2-5.

https://doi.org/10.1038/474S02a

75. Li Q, Wang MY. Use food industry wastes to produce microbial oil. Sci Technol Food Ind. 1997;6:65-9.

76. Ma YL. Microbial oils and its research advance. Chin J Bioprocess Eng. 2006;4:7-11.

77. Ratledge C, Wynn JP.The biochemistry and molecular biology of lipid accumulation in oleaginous microorganisms. Adv Appl Microbiol. 2002;51:1-52.

https://doi.org/10.1016/S0065-2164(02)51000-5

78. Meng X, Yang J, Xu X, Zhang L, Nie Q, Xian M. Biodiesel production from oleaginous microorganisms. Renew Energ. 2009;34(1):1-5.

https://doi.org/10.1016/j.renene.2008.04.014

79. Subramaniam R, Dufreche S, Zappi M, Bajpai R. Microbial lipids from renewable resources: Production and characterization. J Ind Microbiol Biotechnol. 2010;37(12):1271-87. https://doi.org/10.1007/s10295-010-0884-5

80. Ratledge C, Cohen Z. Microbial and algal oils: Do they have a future for biodiesel or as commodity oils? Lipid Technol. 2008;20(7):155-60. https://doi.org/10.1002/lite.200800044

81. Beopoulos A, Chardot T, Nicaud JM. Yarrowia lipolytica: A model and a tool to understand the mechanisms implicated in lipid accumulation. Biochimie. 2009; 91(6):692-6. https://doi.org/10.1016/j.biochi.2009.02.004

82. Christophe G, Kumar V, Nouaille R, Gaudet G, Fontanille P, Pandey $A$, et al. Recent developments in microbial oils production: A possible alternative to vegetable oils for biodiesel without competition with human food? Braz Arch Biol Technol. 2012;55(1):29-46.

https://doi.org/10.1590/S1516-89132012000100004 
83. Ghanem KM, Sabry SA, Yusef HH. Some physiological factors influencing lipid production by Rhodotorula glutinis from Egyptian beet molasses. Med J Islamic World Acad Sci. 1990;3(4):305-9.

84. El-Fadaly HA, El-Naggar NEA, Marwan ESM. Single cell oil production by an oleaginous yeast strain in a low cost cultivation medium. Res J Microbiol. 2009;4(8):301-13. https://doi.org/10.3923/jm.2009.301.313

85. Alvarez RM, Rodríguez B, Romano JM, Díaz AO, Gómez E, Miró $D$, et al. Lipid accumulation in Rhodotorula glutinis on sugar cane molasses in single-stage continuous culture. World J Microbiol Biotechnol. 1992;8(2):214-5. https://doi.org/10.1007/BF01195853

86. Gouda MK, Omar SH, Aouad LM. Single cell oil production by Gordonia sp. DG using agro-industrial wastes. World J Microbiol Biotechnol. 2008;24:1703. https://doi.org/10.1007/s11274-008-9664-z

87. Xu J, Du W, Zhao X, Zhang G, Liu D. Microbial oil production from various carbon sources and its use for biodiesel preparation. Biofuels Bioprod Bioref. 2013;7(1):65-77. https://doi.org/10.1002/bbb.1372

88. Zhao ZB. Toward cheaper microbial oil for biodiesel oil. Chin Biotechnol. 2005;25(2):8-11.

89. Jin M, Slininger PJ, Dien BS, Waghmode S, Moser BR, Orjuela A, et al. Microbial lipid-based lignocellulosic biorefinery: Feasibility and challenges. Trends Biotechnol. 2015;33(1):43-54. https://doi.org/10.1016/j.tibtech.2014.11.005

90. Papanikolaou S, Aggelis G. Lipids of oleaginous yeasts. Part I: Biochemistry of single cell oil production. Eur J Lipid Sci Technol. 2011;113(8):1031-51. https://doi.org/10.1002/ejlt.201100014

91. Li Q, Du W, Liu D. Perspectives of microbial oils for biodiesel production. Appl Microbiol Biotechnol. 2008;80(5):749-56. https://doi.org/10.1007/s00253-008-1625-9

92. Papanikolaou S, Komaitis M, Aggelis G. Single cell oil (SCO) production by Mortierella isabellina grown on high-sugar content media. Bioresour Technol. 2004;95(3):287-91. https://doi.org/10.1016/j.biortech.2004.02.016

93. Aki T, Nagahata Y, Ishihara K, Tanaka Y, Morinaga T, Higashiyama K, et al. Production of arachidonic acid by filamentous fungus, Mortierella alliacea strain YN-15. J Am Oil Chem Soc. 2001;78(6):599-604. https://doi.org/10.1007/s11746-001-0311-2

94. Zabeti N, Bonin P, Volkman JK, Guasco S, Rontani JF. Fatty acid composition of bacterial strains associated with living cells of the haptophyte Emiliania huxleyi. Org Geochem. 2010;41(7):627-36.

https://doi.org/10.1016/j.orggeochem.2010.04.009

95. Roche CM, Glass NL, Blanch HW, Clark DS. Engineering the filamentous fungus Neurospora crassa for lipid production from lignocellulosic biomass. Biotechnol Bioeng. 2014;111(6):1097-107.

https://doi.org/10.1002/bit.25211
96. Verma NM, Mehrotra S, Shukla A, Mishra BN. Prospective of biodiesel production utilizing microalgae as the cell factories: A comprehensive discussion. Afr J Biotechnol. 2010;9(10):1402-11.

https://doi.org/10.5897/AJBx09.071

97. Chen YF, Wu Q. Production of biodiesel from algal biomass: Current perspectives and future. In: Pandey A, Larroche C, Ricke SC, Dussap CG, Gnansounou E, editors. Biofuels - Alternative feedstocks and conversion processes. Oxford, UK: Academic Press; 2011. pp. 399-413.

https://doi.org/10.1016/B978-0-12-385099-7.00018-8

98. Guil-Guerrero JL, Navarro-Juárez R, López-Martínez JC, Campra-Madrid P, Rebolloso-Fuentes MM. Functional properties of the biomass of three microalgal species. J Food Eng. 2004;65(4):511-7.

https://doi.org/10.1016/j.jfoodeng.2004.02.014

99. Spolaore P, Joannis-Cassan C, Duran E, Isambert A. Commercial applications of microalgae. J Biosci Bioeng. 2006;101(2):87-96.

https://doi.org/10.1263/jbb.101.87

100. Pieber S, Schober S, Mittelbach M. Pressurized fluid extraction of polyunsaturated fatty acids from the microalga Nannochloropsis oculata. Biomass Bioenergy. 2012;47:474-82. https://doi.org/10.1016/j.biombioe.2012.10.019

101. Hidalgo P, Toro C, Ciudad G, Schober S, Mittelbach M, Navia R. Evaluation of different operational strategies for biodiesel production by direct transesterification of microalgal biomass. Energy Fuels. 2014;28(6):3814-20.

https://doi.org/10.1021/ef500259z

102. Hidalgo P, Ciudad G, Schober S, Mittelbach M, Navia R. Improving the FAME yield of in situ transesterification from microalgal biomass through particle size reduction and cosolvent incorporation. Energy Fuels. 2015;29(2):823-32. https://doi.org/10.1021/ef5023303

103. Li Y, Zhao ZK, Bai F. High-density cultivation of oleaginous yeast Rhodosporidium toruloides $Y 4$ in fed-batch culture. Enzyme Microb Technol. 2007;41(3):312-7. https://doi.org/10.1016/j.enzmictec.2007.02.008

104. Papanikolaou S, Chevalot I, Komaitis M, Marc I, Aggelis G. Single cell oil production by Yarrowia lipolytica growing on an industrial derivative of animal fat in batch cultures. Appl Microbiol Biotechnol. 2002;58(3):308-12. https://doi.org/10.1007/s00253-001-0897-0

105. Gao J, Chen L, Yan Z, Wang L. Effect of ionic liquid pretreatment on the composition, structure and biogas production of water hyacinth (Eichhornia crassipes). Bioresour Technol. 2013;132:361-4.

https://doi.org/10.1016/j.biortech.2012.10.136

106. Veloso V, Reis A, Gouveia L, Fernandes HL, Empis JA, Novais $J M$. Lipid production by Phaeodactylum tricornutum. Bioresour Technol. 1991;38(2-3):115-9. https://doi.org/10.1016/0960-8524(91)90141-6

107. Chiu SY, Kao CY, Tsai MT, Ong SC, Chen CH, Lin CS. Lipid accumulation and $\mathrm{CO}_{2}$ utilization of Nannochloropsis 
oculata in response to $\mathrm{CO}_{2}$ aeration. Bioresour Technol. 2009;100(2):833-8.

https://doi.org/10.1016/j.biortech.2008.06.061

108. Hsieh $\mathrm{CH}$, Wu WT. Cultivation of microalgae for oil production with a cultivation strategy of urea limitation. Bioresour Technol. 2009;100(17):3921-6.

https://doi.org/10.1016/j.biortech.2009.03.019

109. Feng Y, Li C, Zhang D. Lipid production of Chlorella vulgaris cultured in artificial wastewater medium. Bioresour Technol. 2011;102(1):101-5.

https://doi.org/10.1016/j.biortech.2010.06.016

110. Zhang J, Fang X, Zhu XL, Li Y, Xu HP, Zhao BF, et al. Microbial lipid production by the oleaginous yeast Cryptococcus curvatus $\mathrm{O} 3$ grown in fed-batch culture. Biomass Bioenergy. 2011;35(5):1906-11.

https://doi.org/10.1016/j.biombioe.2011.01.024

111. Chang YH, Chang KS, Hsu CL, Chuang LT, Chen CY, Huang FY, Jang HD. A comparative study on batch and fed-batch cultures of oleaginous yeast Cryptococcus sp. in glucose-based media and corncob hydrolysate for microbial oil production. Fuel. 2013;105:711-7.

https://doi.org/10.1016/j.fuel.2012.10.033

112. Papanikolaou S, Aggelis G. Lipid production by Yarrowia lipolytica growing on industrial glycerol in a single-stage continuous culture. Bioresour Technol. 2002;82(1):43-9. https://doi.org/10.1016/S0960-8524(01)00149-3

113. Ivančić Šantek M, Miškulin E, Petrović M, Beluhan S, Šantek B. Effect of carbon and nitogen source concentrations on the growth and lipid accumulation of yeast Trichosporon oleaginosus in continuous and batch culture. J Chem Technol Biotechnol. 2017;92(7):1620-9.

https://doi.org/10.1002/jctb.5156

114. Ahmad FB, Zhang Z, Doherty WOS, O'Hara IM. Microbial oil production from sugarcane bagasse hydrolysates by oleaginous yeast and filamentous fungi. In: Bruce RC, editor. Proceedings of the 38th Annual Conference of the Australian Society of Sugar Cane Technologists; 2016 April 27-29; Mackay, Australia: Australian Society of Sugar Cane Technologists; 2016. pp. 251-9.

115. Tang D, Han W, Li PL, Miao X, Zhong J. $\mathrm{CO}_{2}$ biofixation and fatty acid composition of Scenedesmus obliquus and Chlorella pyrenoidosa in response to different $\mathrm{CO}_{2}$ levels. Bioresour Technol. 2011;102(3):3071-6.

https://doi.org/10.1016/j.biortech.2010.10.047

116. Fei Q, Chang HN, Shang L, Choi J. Exploring low-cost carbon sources for microbial lipids production by fed-batch cultivation of Cryptococcus albidus. Biotechnol Bioprocess Eng. 2011;16(3):482-7. https://doi.org/10.1007/s12257-010-0370-y

117. Wild R, Patil S, Popović M, Zappi M, Dufreche S, Bajpai R. Lipids from Lipomyces starkeyi. Food Technol Biotechnol. 2010;48:329-35.

118. Huang C, Chen XF, Yang XY, Xiong L, Lin XQ, Yang J. et al. Bioconversion of corncob acid hydrolysate into microbial oil by the oleaginous yeast Lipomyces starkeyi. Appl Biochem Biotechnol. 2014;172(4):2197-204.

https://doi.org/10.1007/s12010-013-0651-y

119. Gao J, Chen L, Yan Z, Wang L. Effect of ionic liquid pretreatment on the composition, structure and biogas production of water hyacinth (Eichhornia crassipes). Bioresour Technol. 2013;132:361-4.

https://doi.org/10.1016/j.biortech.2012.10.136

120. Zeng J, Zheng Y, Yu X, Yu L, Gao D, Chen S. Lignocellulosic biomass as a carbohydrate source for lipid production by Mortierella isabellina. Bioresour Technol. 2013;128:385-91. https://doi.org/10.1016/j.biortech.2012.10.079

121. Economou CN, Aggelis G, Pavlou S, Vayenas DV. Single cell oil production from rice hulls hydrolysate. Bioresour Technol. 2011;102(20):9737-42. https://doi.org/10.1016/j.biortech.2011.08.025

122. Ruan Z, Zanotti M, Zhong Y, Liao W, Ducey C, Liu Y. Co-hydrolysis of lignocellulosic biomass for microbial lipid accumulation. Biotechnol Bioeng. 2013;110(4):1039-49. https://doi.org/10.1002/bit.24773

123. Ruan Z, Zanotti M, Archer S, Liao W, Liu Y. Oleaginous fungal lipid fermentation on combined acid-and alkali-pretreated corn stover hydrolysate for advanced biofuel production. Bioresour Technol. 2014;163:12-7. https://doi.org/10.1016/j.biortech.2014.03.095

124. Jiang L, Luo S, Fan X, Yang Z, Guo R. Biomass and lipid production of marine microalgae using municipal wastewater and high concentration of $\mathrm{CO}_{2}$. Appl Energy. 2011;88(10):3336-41.

https://doi.org/10.1016/j.apenergy.2011.03.043

125. Wei Z, Zeng G, Huang F, Kosa M, Sun Q, Meng X, Huang $D$, Ragauskas AJ. Microbial lipid production by oleaginous Rhodococci cultured in lignocellulosic autohydrolysates. Appl Microbiol Biotechnol. 2015;99(17):7369-77. https://doi.org/10.1007/s00253-015-6752-5

126. Zhao H, Baker GA, Cowins JV. Fast enzymatic saccharification of switchgrass after pretreatment with ionic liquids. Biotechnol Progr. 2010;26(1):127-33. https://doi.org/10.1002/btpr.331.

127. Fei Q, O'Brien M, Nelson R, Chen X, Lowell A, Dowe N. Enhanced lipid production by Rhodosporidium toruloides using different fed-batch feeding strategies with lignocellulosic hydrolysate as the sole carbon source. Biotechnol Biofuels. 2016;9:130. https://doi.org/10.1186/s13068-016-0542-x

128. Saenge C, Cheirsilp B, Suksaroge TT, Bourtoom T. Potential use of oleaginous red yeast Rhodotorula glutinis for the bioconversion of crude glycerol from biodiesel plant to lipids and carotenoids. Process Biochem. 2011;46(1):210-8. https://doi.org/10.1016/j.procbio.2010.08.009

129. Ho SH, Chen WM, Chang JS. Scenedesmus obliquus CNW-N as a potential candidate for $\mathrm{CO}_{2}$ mitigation and biodiesel production. Bioresour Technol. 2010;101(22):8725-30. https://doi.org/10.1016/j.biortech.2010.06.112 
130. Papanikolaou S, Diamantopoulou P, Chatzifragkou A, Philippoussis A, Aggelis G. Suitability of low-cost sugars as substrates for lipid production by the fungus Thamnidium elegans. Energy Fuels. 2010;24(7):4078-86.

https://doi.org/10.1021/ef1004804

131. Holm-Nielsen JB, Al Seadi T, Oleskowicz-Popiel P. The future of anaerobic digestion and biogas utilization. Bioresour Technol. 2009;100(2):5478-84. https://doi.org/10.1016/j.biortech.2008.12.046

132. Weiland P. Biogas production: Current state and perspectives. Appl Microbiol Biotechnol. 2010;85(4):849-60. https://doi.org/10.1007/s00253-009-2246-7

133. Ryckebosch E, Drouillon M, Vervaeren H. Techniques for transformation of biogas to biomethane. Biomass Bioenergy. 2011;35(5):1633-45.

https://doi.org/10.1016/j.biombioe.2011.02.033

134. Harikishan S. Pretreatment of high-solids wastes/residues to enhance bioenergy recovery. In: Khanal SK, editor. Anaerobic biotechnology for bioenergy production: Principles and applications. lowa, USA: Wiley Blackwell; 2008. pp. 247-65. https://doi.org/10.1002/9780813804545.ch11

135. WBA global bioenergy statistics 2017. Stockholm, Sweden: World Bioenergy Association (WBA); 2017. Available from: http://worldbioenergy.org/uploads/WBA\%20GBS\%20 2017_hq.pdf.

136. Statistical report 2017. European Biogas Association (EBA); 2017. Brussels, Belgium. Available from: https://european-biogas.eu/wp-content/uploads/2017/12/Statistical-report-of-the-European-Biogas-Association_excerpt-web. pdf.

137. Flach B, Leiberz S, Rossetti A, Phillips S. EU biofuels annual 2017. Washington, DC, USA: USDA Foreign Agricultural Service. Available from:

https://gain.fas.usda.gov/Recent\%20GAIN\%20Publications/Biofuels\%20Annual_The\%20Hague_EU-28_6-192017.pdf.

138. Frigon JC, Guiot SR. Biomethane production from starch and lignocellulosic crops: A comparative review. Biofuels Bioprod Bioref. 2010;4(4):447-58. https://doi.org/10.1002/bbb.229

139. Zheng Y, Zhao J, Xu F, Li Y. Pretreatment of lignocellulosic biomass for enhanced biogas production. Prog Energy Combust Sci. 2014;42:35-53. https://doi.org/10.1016/j.pecs.2014.01.001

140. Schink B. Energetics of syntrophic cooperation in methanogenic degradation. Microbiol Mol Biol Rev. 1997;61(2):26280.

141. Bischoff M. Knowledge in the use of additives and excipients as well as trace elements in biogas plants; VDI Reports no. 2057: 'Biogas 2009 - Energy source of the future'. Düsseldorf, Gremany: VDI Verlag; 2009. pp. S111-23 (in German).

142. Mao C, Feng Y, Wang X, Ren G. Review on research achievements of biogas from anaerobic digestion. Renew Sust En- erg Rev. 2015;45:540-55

https://doi.org/10.1016/j.rser.2015.02.032

143. Zhao J. Enhancement of methane production from solid-state anaerobic digestion of yard trimmings by biological pretreatment [MSc Thesis]. Columbus, OH, USA: The Ohio State University; 2013.

144. Parawira W, Read JS, Mattiasson B, Björnsson L. Energy production from agricultural residues: High methane yields in a pilot-scale two-stage anaerobic digestion. Biomass Bioenergy. 2008;32(1):44-50.

https://doi.org/10.1016/j.biombioe.2007.06.003

145. Angelidaki I, Ellegaard L, Ahring BK. Application of the anaerobic digestion process. In: Ahring BK, Andelidaki I, Dolfing J, Euegaard L, Gavala HN, Haagensen F, et al., editors. Biomethanation II: Advances in Biochemical Engineering/ Biotechnology, vol. 82. Heidelberg, Germany: Springer; 2003. pp. 1-33.

https://doi.org/10.1007/3-540-45838-7_1

146. Weiland P. The state of the art in dry fermentation. Gülzower Fachgespräche. 2006;24:22-38 (in German).

147. Heiermann M, Linke B, Kessler U, Loock R. Biogas from renewable resources through dry anaerobic digestion. Landtechnik. 2007;62:14-15.

148. Lehtomäki A, Björnsson L. Two-stage anaerobic digestion of energy crops: Methane production, nitrogen mineralisation and heavy metal mobilisation. Environ Technol. 2006;27(2):209-18. https://doi.org/10.1080/09593332708618635

149. Weiland P, Verstraete W, van Haandel A. Biomass digestion to methane in agriculture: A successful pathway for the energy production and waste treatment worldwide. In: Soetaert W, Vandamme EJ, editors. Biofuels. Chichester, UK: John Wiley \& Sons, Ltd; 2009. pp. 171-95. https://doi.org/10.1002/9780470754108.ch10

150. De Baere L, Mattheeuws B. State-of-the-art 2008 - Anaerobic digestion of solid waste. Waste Manage World. 2008;9(4):1-6.

151. Brown D, Shi J, Li Y. Comparison of solid-state to liquid anaerobic digestion of lignocellulosic feedstocks for biogas production. Bioresour Technol. 2012;124:379-86. https://doi.org/10.1016/j.biortech.2012.08.051

152. Zhu J, Zheng Y, Xu F, Li Y. Solid-state anaerobic co-digestion of hay and soybean processing waste for biogas production. Bioresour Technol. 2014;154:240-7. https://doi.org/10.1016/j.biortech.2013.12.045

153. Kaparaju P, Serrano M, Angelidaki I. Effect of reactor configuration on biogas production from wheat straw hydrolysate. Bioresour Technol. 2009;100(24):6317-23. https://doi.org/10.1016/j.biortech.2009.06.101

154. Chen L, Gu Y, Cao C, Zhang J, Ng JW, Tang C. Performance of a submerged anaerobic membrane bioreactor with forward osmosis membrane for low-strength wastewater 
treatment. Water Res. 2014;50:114-23.

https://doi.org/10.1016/j.watres.2013.12.009

155. Bo T, Zhu X, Zhang L, Tao Y, He X, Li D, Yan Z. A new upgraded biogas production process: Coupling microbial electrolysis cell and anaerobic digestion in single-chamber, barrel-shape stainless steel reactor. Electrochem Commun. 2014:45:67-70.

https://doi.org/10.1016/j.elecom.2014.05.026

156. Taherzadeh MJ, Karimi K. Pretreatment of lignocellulosic wastes to improve ethanol and biogas production: A review. Int J Mol Sci. 2008;9(9):1621-51. https://doi.org/10.3390/ijms9091621

157. Mirahmadi K, Kabir MM, Jeihanipour A, Karimi K, Taherzadeh $\mathrm{M}$. Alkaline pretreatment of spruce and birch to improve bioethanol and biogas production. Bioresources. 2010;5(2):928-38.

158. O-Thong S, Boe K, Angelidaki I. Thermophilic anaerobic co-digestion of oil palm empty fruit bunches with palm oil mill effluent for efficient biogas production. Appl Energy. 2012;93:648-54.

https://doi.org/10.1016/j.apenergy.2011.12.092

159. Salehian P, Karimi K. Alkali pretreatment for improvement of biogas and ethanol production from different waste parts of pine tree. Ind Eng Chem Res. 2013;52(2):972-8. https://doi.org/10.1021/ie302805c

160. Song Z, Yang G, Guo Y, Zhang T. Comparison of two chemical pretreatments of rice straw for biogas production by anaerobic digestion. Bioresources. 2012;7(3):3223-36.

161. Monlau F, Latrille E, Carvalho Da Costa A, Steyer JP, Carrère $\mathrm{H}$. Enhancement of methane production from sunflower oil cakes by dilute acid pretreatment. Appl Energy. 2013;102:1105-13.

https://doi.org/10.1016/j.apenergy.2012.06.042

162. Monlau F, Barakat A, Steyer JP, Carrère H. Comparison of seven types of thermo-chemical pretreatments on the structural features and anaerobic digestion of sunflower stalks. Bioresour Technol. 2012;120:241-7. https://doi.org/10.1016/j.biortech.2012.06.040

163. Cuissinat C, Navard P. Swelling and dissolution of cellulose part 1: Free floating cotton and wood fibers in N-methylmorpholine-N-oxide-water mixtures. Macromol Symp. 2006;244(1):1-18. https://doi.org/10.1002/masy.200651201

164. Kabir MM, Niklasson C, Taherzadeh MJ, Horváth IS. Biogas production from lignocelluloses by $\mathrm{N}$-methylmorpholine-N-oxide (NMMO) pretreatment: Effects of recovery and reuse of NMMO. Bioresour Technol. 2014;161:446-50. https://doi.org/10.1016/j.biortech.2014.03.107

165. Goshadrou A, Karimi K, Taherzadeh MJ. Ethanol and biogas production from birch by NMMO pretreatment. Biomass Bioenergy. 2013;49:95-101. https://doi.org/10.1016/j.biombioe.2012.12.013

166. Kabir MM, del Pilar Castillo M, Taherzadeh MJ, Sárvári Horváth I. Effect of the $\mathrm{N}$-methylmorpholine-N-oxide (NMMO) pretreatment on anaerobic digestion of forest residues. Bioresources. 2013;8(4):5409-23.

https://doi.org/10.15376/biores.8.4.5409-5423

167. Teghammar A, Karimi K, Sárvári Horváth I, Taherzadeh MJ. Enhanced biogas production from rice straw, triticale straw and softwood spruce by NMMO pretreatment. Biomass Bioenergy. 2012;36:116-20.

https://doi.org/10.1016/j.biombioe.2011.10.019

168. Petersson A, Thomsen $\mathrm{MH}$, Hauggaard-Nielsen $\mathrm{H}$, Thomsen $A B$. Potential bioethanol and biogas production using lignocellulosic biomass from winter rye, oilseed rape and faba bean. Biomass Bioenergy. 2007;31(11-12):812-9. https://doi.org/10.1016/j.biombioe.2007.06.001

169. Sapci Z. The effect of microwave pretreatment on biogas production from agricultural straws. Bioresour Technol. 2013;128:487-94. https://doi.org/10.1016/j.biortech.2012.09.094

170. Jackowiak D, Bassard D, Pauss A, Ribeiro T. Optimisation of a microwave pretreatment of wheat straw for methane production. Bioresour Technol. 2011;102(12):6750-6. https://doi.org/10.1016/j.biortech.2011.03.107

171. Cesaro A, Naddeo V, Amodio V, Belgiorno V. Enhanced biogas production from anaerobic codigestion of solid waste by sonolysis. Ultrason Sonochem. 2012;19(3):596-600. https://doi.org/10.1016/j.ultsonch.2011.09.002

172. Hjorth M, Gränitz K, Adamsen APS, Møller HB. Extrusion as a pretreatment to increase biogas production. Bioresour Technol. 2011;102(8):4989-94. https://doi.org/10.1016/j.biortech.2010.11.128

173. Mackulak T, Prousek J, Švorc L, Drtil M. Increase of biogas production from pretreated hay and leaves using wood-rotting fungi. Chem Pap. 2012;66(7):649-53. https://doi.org/10.2478/s11696-012-0171-1

174. Zhang Q, He J, Tian M, Mao Z, Tang L, Zhang J, Zhang H. Enhancement of methane production from cassava residues by biological pretreatment using a constructed microbial consortium. Bioresour Technol. 2011;102(19):8899-906. https://doi.org/10.1016/j.biortech.2011.06.061

175. Ziemiński K, Romanowska I, Kowalska M. Enzymatic pretreatment of lignocellulosic wastes to improve biogas production. Waste Manag. 2012;32(6):1131-7. https://doi.org/10.1016/j.wasman.2012.01.016

176. Carlsson AS, van Beilen JB, Möller R, Clayton D. Micro- and macro-algae: Utility for industrial applications. In: Bowles D, editor. Outputs from the EPOBIO project, September 2007. Newburry, UK: CPL Press; 2007. Available from: http://www.etipbioenergy.eu/images/epobio_aquatic_report.pdf.

177. Koller M, Muhr A, Braunegg G. Microalgae as versatile cellular factories for valued products. Algal Res. 2014;6(Pt A):52-63.

https://doi.org/10.1016/j.algal.2014.09.002 
178. Sigot L, Ducom G, Benadda B, Labouré C. Comparison of adsorbents for $\mathrm{H}_{2} \mathrm{~S}$ and $\mathrm{D} 4$ removal for biogas conversion in a solid oxide fuel cell. Environ Technol. 2016;37(1):86-95. https://doi.org/10.1080/09593330.2015.1063707

179. Micoli L, Bagnasco G, Turco M. $\mathrm{H}_{2} \mathrm{~S}$ removal from biogas for fuelling MCFCs: New adsorbing materials. Int J Hydrog Energy. 2014;39(4):1783-7.

https://doi.org/10.1016/j.ijhydene.2013.10.126

180. Krayzelova L, Bartacek J, Kolesarova N, Jenicek P. Microaeration for hydrogen sulfide removal in UASB reactor. Bioresour Technol. 2014;172:297-302.

https://doi.org/10.1016/j.biortech.2014.09.056

181. Dolejš P, Poštulka V, Sedláková Z, Jandová V, Vejražka J, Esposito $E$, et al. Simultaneous hydrogen sulphide and car- bon dioxide removal from biogas by water-swollen reverse osmosis membrane. Sep Purif Technol. 2014;131:108-16. https://doi.org/10.1016/j.seppur.2014.04.041

182. Li Q, Fan S, Wang Y, Lang X, Chen J. CO removal from biogas based on hydrate formation with tetra-n-butylammonium bromide solution in the presence of 1-butyl-3-methylimidazolium tetrafluoroborate. Energy Fuels. 2015;29(5):3143-8. https://doi.org/10.1021/acs.energyfuels.5b00061

183. Xiao Y, Yuan H, Pang Y, Chen S, Zhu B, Zou D, et al. CO removal from biogas by water washing system. Chinese $J$ Chem Eng. 2014;22(8):950-3.

https://doi.org/10.1016/j.cjche.2014.06.001 